\title{
Spectrometric measurements and DFT studies on new complex of copper (II) with
}

\section{2-( (E)-9-ethyl-3-(2-(6-(4-methylpyridin-2-yl)pyridin-3-yl)vinyl)-9H-carbazole}

Haoyang Zhang, Jie Hu, Jianying Zhao*, Yu Zhang*

Huaian Key Laboratory for Photoelectric Conversion and Energy Storage Materials, School of Chemistry and Chemical Engineering, Huaiyin Normal University, Huai'an 223300, Jiangsu, P. R. China

\section{Abstract:}

The molecular structure of a new coordination compound of copper (II) with (E)-9-ethyl-3-(2-(6-(4-methylpyridin-2-yl)pyridin-3-yl)vinyl)-9H-carbazole ( $\left[\mathrm{Cu}_{2}(\mathrm{emppc})_{2} \mathrm{Cl}_{2}\right] \mathrm{Cl}_{2}$ ) was optimized with B3LYP/LanL2DZ, PBE1PBE/LanL2DZ and M062X/LanL2DZ theoretical level. The ligand, (E)-9-ethyl-3-(2-(6-(4-methylpyridin-2-yl)pyridin-3-yl)vinyl)-9H-carbazole (emppc), binds to $\mathrm{Cu}$ (II) ions with a bi-dentate mode, two $\mathrm{Cl}^{-}$serve as bridging ligand, each $\mathrm{Cu}(\mathrm{II})$ ion has a highly distorted tetrahedron coordination geometry. With M062X/LanL2DZ theoretical level, the calculated interaction energies of $\mathrm{Cu}$ (II) with coordination atoms $\mathrm{N}$ are between 183.3-200.0 kJ/mol for $\alpha$ spin and 319.4-324.9 $\mathrm{kJ} / \mathrm{mol}$ for $\beta$ spin, and interaction energies of $\mathrm{Cu}(\mathrm{II})$ with coordination atoms $\mathrm{Cl}$ atom are $248.0-252.4 \mathrm{~kJ} / \mathrm{mol}$ for $\alpha$ spin and 332.6-333.6 $\mathrm{kJ} / \mathrm{mol}$ for $\beta$ spin. The experimental Fourier transform infrared spectrum was assigned. The calculated IR based on B3LYP/LanL2DZ, PBE1PBE/LanL2DZ and M062X/LanL2DZ methods were performed and compared with experimental results. The UV-Vis experimental spectrum of $\left[\mathrm{Cu}_{2}(\mathrm{emppc})_{2} \mathrm{Cl}_{2}\right] \mathrm{Cl}_{2}$ was measured in methanol solution. The calculated electronic spectra was performed with TD/M062X and PCM-TD/M062X methods with LanL2DZ basis set. Calculated vibration wavenumbers, UV-Vis absorption wavelengths are in good agreement with the experimental results. The nature bond orbital analysis and temperature dependence of the thermodynamic properties were calculated with the same methods.

Keywords: vibrational spectra; electronic spectra; NBO; DFT; $\left[\mathrm{Cu}_{2}(\mathrm{emppc})_{2} \mathrm{Cl}_{2}\right] \mathrm{Cl}_{2}$

\section{Introduction}

2,2'-Bipyridine and its derivatives are a kind of well known bidentate chelating agent for transition metal ions mainly for its availability, strong redox stability and relative ease of functionalization[1-4] and still continues to be of considerable interest 
as versatile starting material for organic, inorganic and supramolecular chemistry[5-9]. Their abilities to absorb visible light to act as electron reservoirs are promising factors in their applications as photosensitizers. For example, the ruthenium complexes with 2,2'-bipyridine derivatives are generally recognized as a class of the most excellent dye for dye-sensitized solar cells. Grätzel research group[10] reported cis-bis( 2,2'-bipyridyl-4,4'-dicarboxylate)(SCN $)_{2}$ ruthenium(II)(N3) in 1993, the compound gives the photoelectric energy conversion efficiency reached $10 \%$. If butyl ammonium salt introduced to N3, the photoelectric conversion efficiency reached $11.18 \%[11]$.

Transition metal complexes of 2,2'-bipyridine and their derivatives are of great interest also due to their ability to undergo facile electrochemical processes and can be used as efficiently catalysis. Lehn[12] reported the earliest metal complexes $\left[\mathrm{Re}(\mathrm{bpy})(\mathrm{CO})_{3} \mathrm{Cl}_{2}\right]$, the compound shown efficiently to catalyze the electrochemical conversion of $\mathrm{CO}_{2}$ to $\mathrm{CO}$. Kubiak[13] demonstrated that the activity of this complex could be vastly improved by utilizing a modified bpy ligand containing tert-butyl groups. More recently, Shunsuke Sato[14] reported an efficient photocatalyst, [Ir-Meppy], which has the TNCO value up to 50, and the quantum yield FCO up to 0.21 .

Transition metal complexes of 2,2'-bipyridine and their derivatives has become one of the most powerful and extensively used tools fluorescent imaging and sensing in cell biology, physiology, and related areas of the biomedical sciences [15]. For example, Puckett and Barton found that the introduction of more lipophilic bipyridyl ligands improved uptake and allowed luminescence imaging to be carried out without the need for membrane permeation they studied a series of analogues of $[\mathrm{Ru}(\mathrm{bpy}) 2(\mathrm{dppz})] 2+(\mathrm{dppz}=1,3-\mathrm{di}(2-$ pyridyl)benzene) [16], these compounds exhibited high cellular luminescence, detectable even using concentrations less than $1 \mu \mathrm{M}$. Hagimori [17] reported a high-affinity and low-molecular-weight fluorescent sensor based on a 2,2'-bipyridine scaffold, which functions as both the chelating moiety for $\mathrm{Zn}^{2+}$ and the fluorophore, was developed and evaluated in biological applications.

Further, transition metal complexes of 2,2'-bipyridine and their derivatives can be used widely in extraordinary molecular architectures [18-20]. Many of these compounds have been designed to be used in the assembly of 0-D to 3-D polymeric complexes which consist of mononuclear building blocks bridged by transition metal 
or lanthanide ions[21-24]. Highlights include single molecule magnets[25,26], metal-organic frameworks[27,28] and materials which display organic electronic[29], spin crossover [30] and luminescence[31].

Although new developments in synthesis and applications have been reported, the spectroscopic properties of such compounds were not extensively studied $[32,33]$. Herein, we describe our results on a new binuclear compound, $\left[\mathrm{Cu}_{2}(\mathrm{emppc})_{2} \mathrm{Cl}_{2}\right] \mathrm{Cl}_{2}$, concerning the structural, vibrational and electronic analyses through spectral measurements. Density Functional theory calculations have been performed to support our wavenumber assignments. The redistribution of Electron Density (ED) in various bonding, antibonding orbitals and $\mathrm{E}(2)$ energies have been calculated by natural bond orbital (NBO) analysis to provide evidence of stabilization originating from the hyperconjugation and various intramolecular interactions. UV-Vis spectra were measured in methanol solution. The transition energies and oscillator strengths were calculated with time dependent (TD) method to assign of charge transference (CT) electronic bands. To our best knowledge, this is the first report on the synthesis, spectral measurements and computational study of this compound. The calculated results were compared with the observed spectra. Calculated vibration wavenumbers, $\mathrm{UV}-\mathrm{Vis}$ absorption wavelengths are in good agreement with the experimental results.

\section{Experimental and calculation}

\subsection{Synthesis of $\left[\mathrm{Cu}_{2}(\mathrm{emppc})_{2} \mathrm{Cl}_{2}\right] \mathrm{Cl}_{2}$}

\subsubsection{Synthesis of (E)-9-ethyl-3-(2-(6-(4-methylpyridin-2-yl)pyridin-3-yl)vinyl)}

\section{-9H-carbazole (emppc)}

(E)-9-ethyl-3-(2-(6-(4-methylpyridin-2-yl)pyridin-3-yl)vinyl)-9H-carbazole (emppc) was obtained according to the previous report[34] with slight modification. $1.84 \mathrm{~g} \quad(10.0 \mathrm{mmol})$ 4,4'-methyl-2,2'-bipyridine and $2.23 \mathrm{~g} \quad(10 \mathrm{mmol})$ N-Ethyl-3-carbazolecarboxaldehyde was slowly added into a $100 \mathrm{~mL}$ three-necked flask with $20 \mathrm{~mL} \mathrm{DMF}$, potassium tert-butoxide was used as catalyst. The mixture was stirred for $20 \mathrm{~min}$ at room temperature and heated to $100{ }^{\circ} \mathrm{C}$ for $9 \mathrm{~h}$. Yellow powder yielded and recrystallized with ethanol. Yield: 37.2\%. 1HNMR (400 MHz, CDCl3): $\delta(\mathrm{ppm}){ }^{1} \mathrm{HNMR}\left(400 \mathrm{MHz}, \mathrm{CDCl}_{3}\right): \delta(\mathrm{ppm}) 8.63\left(\mathrm{~d}, 1 \mathrm{H}, \mathrm{H}^{6}\right), 8.59(\mathrm{~d}, 1 \mathrm{H}$, $\left.\mathrm{H}^{6^{\prime}}\right), 8.55\left(\mathrm{~d}, 1 \mathrm{H}, \mathrm{H}^{3}\right), 8.27\left(\mathrm{~s}, 2 \mathrm{H}, \mathrm{H}^{3}, \mathrm{Ar}\right), 8.13(\mathrm{~d}, 1 \mathrm{H}, \mathrm{Ar}), 7.71(\mathrm{~d}, 1 \mathrm{H}, \mathrm{Ar}), 7.66(\mathrm{~d}$, $\left.1 \mathrm{H}, \mathrm{H}^{6}\right), 7.49$ (m, 1H,Ar), $7.41\left(\mathrm{~m}, 3 \mathrm{H}, \mathrm{H}^{3}, \mathrm{H}^{5}, \mathrm{Ar}\right), 7.27$ (m, 1H, Ar), $4.36\left(\mathrm{q}, 2 \mathrm{H}, \mathrm{CH}_{2^{-}}\right)$, $2.45\left(\mathrm{~s}, 3 \mathrm{H}, \mathrm{CH}_{3}\right), 1.44\left(\mathrm{t}, 3 \mathrm{H}, \mathrm{CH}_{3}\right)$. ESI-MS [m/z]: $390.4[\mathrm{M}+\mathrm{H}]^{+}$

\subsubsection{Preparation of $\left[\mathrm{Cu}_{2}(\mathrm{emppc})_{2} \mathrm{Cl}_{2}\right] \mathrm{Cl}_{2}$}


To a solution of $\mathrm{CuCl}_{2} \cdot 2 \mathrm{H}_{2} \mathrm{O}(0.275 \mathrm{~g}, 1.0 \mathrm{mmol})$ in methanol $(10 \mathrm{~mL})$, a solution of emppc $(0.389 \mathrm{~g}, 1.0 \mathrm{mmol})$ in methanol $(20 \mathrm{~mL})$ was added dropwise with magnetic stirring. The resulting solution turned brown. The mixture was stirred at room temperature for $3 \mathrm{~h}$ and filtered. Deep brown powder yielded and recrystallized with DMF and ethanol. (ca. 86\% yield based on emppc). Anal. calcd. for C56H46N6Cl4Cu2 (\% ): C, 57.58; H, 3.94; N, 7.20; Found (\%): C, 57.36; H, 3.92; N, 7.454. ESI-MS [m/z]: $548.2[\mathrm{M}] 2+$

\subsection{Spectral characterization}

The FT-IR spectrum of the title compound was measured on AVATAR360 spectrophotometer in the range of $500-4000 \mathrm{~cm}^{-1}$ at room temperature using $\mathrm{KBr}$ pellet technique. The UV-Vis spectrum was recorded on UV-Vis 916 spectrophotometer in the region $225-600 \mathrm{~nm}$ using methanol as solvent.

\subsection{Methods of calculation}

In recent years, density functional theory (DFT) has emerged as a powerful tool in studying vibrational spectra, electronic spectra, and the physical properties of molecules. The DFT calculations are reported to provide excellent vibrational frequencies of organic compounds and metal complexes[35-38]. Therefore, we have utilized the gradient corrected DFT with the Becke's three-parameter hybrid functional (B3) for the exchange part and the Lee-Yang-Parr (LYP) correlation function, B3LYP [39], PBE1PBE[40] and M062X[41] accepted as a cost-effective approach, for the computation of molecular structure, vibrational frequencies and energies of optimized structures[42,44]. Based on the previous studies[44,45], these methods and a fairly large and flexible basis set LanL2DZ level to perform accurate calculations on the title molecule were chosen. DFT calculations were generally carried out with the spin restricted RDFT approach for closed shell and with the spin unrestricted UDFT approach for open shell compounds. For the investigated complexes, the ground state geometries were calculated in the gas phase using the unrestricted Kohn-Sham formalism (UKS) with unrestricted B3LYP functional (UB3LYP). Geometry optimization proceeded in two steps, firstly, the initial geometry was constructed by $\mathrm{MM}+$ molecular modeling in HyperChem 6.0 package[46]. Then the geometry was optimized by density functional theory (DFT) B3LYP, PBE1PBE and M062X methods with LanL2DZ basis set. The vibrational calculations were performed. No imaginary mode was observed. The study of the molecular orbitals was carried out using the Mulliken population analysis and a 
graphical analysis with the Chemcraft and GaussSum[447] programs. The calculations of the transition energies and the oscillator strengths in the UV-Vis spectra were based on the optimized structures. The calculations were carried out using the TD method implemented in the Gaussian09[48]. Transition moment calculations were based on M062X theoretical level. The incorporation of the solvent effect in the TD method, using the polarizable calculation model (PCM)[49], was carried out with methanol. Finally, to corroborate the previous observations, the analysis of the variation of the electronic density of this compound was carried out through natural bond orbital (NBO).

\section{Results and discussion}

\subsection{Structural description}

The optimized geometry with atomic numbering scheme for the title compound is shown in Fig. 1. The predicted geometric parameters (bond lengths, bond angles and dihedral angles) of the investigated structures are collected in Table 1. In the complex cation, each $\mathrm{Cu}(\mathrm{II})$ is bonded to two $\mathrm{Cl}^{-}$ligand and one emppc ligands which coordinate through two bpy nitrogen atoms, forming five-membered chelate rings. The geometry around the copper atom can be described as a highly distorted tetrahedron. The calculated $\mathrm{Cu}(\mathrm{II})-\mathrm{N}$ are $2.0398 \AA$ for $\mathrm{Cu}-\mathrm{N} 20$ and $2.0269 \AA$ for $\mathrm{Cu}-\mathrm{N} 25$ with B3LYP theoretical level, these values are comparable with the experimental results ca. $2.0 \AA$ in the compound $\left[\mathrm{Cu}\left(2,2^{\prime}\right.\right.$-bipy $\left.)(\operatorname{Htda})\right] \mathrm{n}\left(2,2^{\prime}\right.$-bipy = 2,2'-bipyridine, Htda=1,2,3-triazole-4,5-dicarboxylate)[50]. The calculated $\mathrm{Cu}(\mathrm{II})-\mathrm{Cl}$ bond distance are ca. $2.40 \AA$ with B3LYP theoretical level, these values are comparable with the experimental results $2.30 \AA$ in the compound $\mathrm{Cu}(\mathrm{bpy})_{2}(\mu-\mathrm{Cl})_{2} \mathrm{Cl}_{2}[51]$. The calculated N57-Cu59-Cl09 bond angle $158.4^{\circ}$ and $\mathrm{N} 20-\mathrm{Cu} 54-\mathrm{Cu} 110$ bond angle $158.8^{\circ}$. In the compound, the C5-N9 (1.4137 $\AA$ ) is typical single bond which is very close to the calculated values in all methods. The calculated bond length of C19-N20 and (1.3467 $\AA$ ) is shorter than C24N55 (1.3698 $)$ bond length, but significantly longer than the typical $\mathrm{C}=\mathrm{N}$ double bond since the conjugation effects. [52,53]

\subsection{The infrared spectrum of $\left[\mathrm{Cu}_{2}(\operatorname{emppc})_{2} \mathrm{Cl}_{2}\right] \mathrm{Cl}_{2}$ and DFT calculations}

In the present study, we performed a frequency calculation analysis to obtain the spectroscopic signature of the compound. The compound had 324 vibrational normal modes. The selected harmonic vibrational frequencies were given in Table 2. Also, the calculated FT-IR spectra for the compounds were shown in Fig. 2. None of the 
predicted vibrational spectra had any imaginary frequency, proving that optimized geometry was located at the lowest point on the potential energy surface. It is well known fact that DFT levels systematically overestimate the vibrational wave-numbers[54]. Therefore, the scaling factor values were used in order to correct anharmonicity and neglected part of electron correlation. The scale factor for the frequencies scaling was used as 0.9650 for B3LYP, 0.9516 for PBE1PBE and 0.9480 for M062X.

The vibrational assignments have been made on the basis of visualization of the atomic displacements in each calculated normal mode and by comparison with the assignments reported earlier for other similar systems [55,56]. As is seen in Fig. 2, The observed bands at 3068, 2976 and $2930 \mathrm{~cm}^{-1}$ are the $\mathrm{CH}$ stretching mode of $\mathrm{C} 16(17) \mathrm{H}, \mathrm{C} 14 \mathrm{H}$ and $\mathrm{C} 46 \mathrm{H}$, the corresponding B3LYP/LanL2DZ calculated values for these vibrations are 3170,3090 and $3051 \mathrm{~cm}^{-1}$, respectively. The observed values 1615,1475 and $1413 \mathrm{~cm}^{-1}$ and corresponding calculated values 1672, 1527 and 1475 $\mathrm{cm}^{-1}$ can be assigned to coupled vibrational modes of $\mathrm{CC}$ stretching and $\mathrm{CH}$ wagging in plane vibrational modes of carbazole ring. The $\mathrm{CC}$ stretching vibrational modes of bpy are found in the observed bands 1588, 1558, 1335, 1287, 1235 and $1179 \mathrm{~cm}^{-1}$, PED analysis found that the first mode is strongly coupled with $\mathrm{CH}$ wagging in plane mode of $\mathrm{C}(\mathrm{bpy}) \mathrm{H}(\mathrm{PED}, 49 \%)$, the second mode is coupled with CC stretching mode of carbazole(PED, 19\%), $\mathrm{CH}$ wagging in plane mode of $\mathrm{C}(\mathrm{bpy}) \mathrm{H}(\mathrm{PED}, 12 \%)$ and $\mathrm{CH}$ wagging in plane mode of $\mathrm{C}($ carbazole $) \mathrm{H}(\mathrm{PED}, 14 \%)$. The observed band $1085 \mathrm{~cm}^{-1}$ and corresponding theoretical value $1133 \mathrm{~cm}^{-1}$ can be assigned to the coupled vibrational mode of carbazole ring breath mode( $\mathrm{PED}, 17 \%)$ with $\mathrm{CH}$ wagging in plane mode of carbazole(PED, 24\%) and the torsion mode of HC95C96H(PED, 22\%).

The observed band $1026 \mathrm{~cm}^{-1}$ and corresponding theoretical value $1075 \mathrm{~cm}^{-1}$ can be assigned to the coupled vibrational mode of N90C95 stretching vibrational mode(PED, $15 \%$ ) with C95C96 stretching vibrational mode(PED, 22\%), CCC bending mode of carbazole(PED, 28\%) and wagging in plane mode $\mathrm{CH}$ in carbazole ring (PED, 47\%). Compared with the experimental values for these modes, the calculated results overestimate the frequencies with errors $2.5-4.8 \%, 3.0-6.9 \%$ and $4.3-7.5 \%$ for B3LYP, PBE1PBE and M062X, respectively.

\subsection{The UV-Vis spectrum of $\left[\mathrm{Cu}_{2}(\mathrm{emppc})_{2} \mathrm{Cl}_{2}\right] \mathrm{Cl}_{2}$ and DFT calculations}

\subsubsection{Molecular orbitals for $\left[\mathrm{Cu}_{2}(\operatorname{emppc})_{2} \mathrm{Cl}_{2}\right] \mathrm{Cl}_{2}$}

The energy levels of the frontier orbital of the compound calculated with 
M062X/LanL2DZ theoretical level are listed in Table 3. The 3D plots of the HOMOs and LUMOs of the compound are shown in Fig. 3. The experimental and simulated spectra with M062X/LanL2DZ are shown in Fig. 4. The energy levels of the frontier orbital of the compound are listed in Table 3. For a spin, HOMO, HOMO-3, HOMO-4 and HOMO-5 have $>90 \%$ contribution of emppc ligand, while HOMO-2 and HOMO-6 have mainly contribution of $d$ orbital of $(\mathrm{Cu})$ along with a significantly contribution of $\mathrm{Cl}$. The LUMO has $98 \% \pi /(\mathrm{L})$ character, and delocalized on the emppc ligand. The LUMO+1 electrons are mainly delocalized on the bpy(85.15\%) and seldom from $\mathrm{Cu}$ d orbital (1.81\%). The Koopmans' energy difference between the highest occupied and the lowest unoccupied orbitals, $\operatorname{HOMO}(\alpha)-\operatorname{LUMO}(\alpha)$ gap, was $3.21 \mathrm{eV}$ for the M062X. For $\beta$-spin, HOMO are mainly delocalized on the carbazole $\operatorname{ring}(80.68 \%)$ and some from bpy $(8.33 \%)$, significant contributions of the $\mathrm{d}(\mathrm{Cu})$ orbitals have been found in HOMO-2(47.87\%), HOMO-6(68.82 \%). The LUMO mainly delocalized on the ligand ring. The LUMO+1 has significantly $\mathrm{Cu}$ character along with a significant contribution from $\mathrm{Cl}(12.57 \%)$ and bpy(28.00\%). The participation of the metal orbitals were consistent with the evaluation of multiplicity adopts for $\mathrm{d}^{7} \mathrm{Cu}(\mathrm{II})$, duplet for one unpaired electron.

The analysis of the molecular orbitals obtained with the PCM methodology, which incorporate the solvent effect, present some differences of HOMO, LUMO energy in both methods. However, the order of the frontier orbitals was not changed.

\subsubsection{Electronic spectra}

The electronic absorption spectrum of the ligand and the title compound in methanol solvent was recorded within 225-500 nm range and representative spectrum is given in Fig. 4. For comparison, the calculated UV-Vis with different methods is also showed in the Fig. 4. The energies and oscillator strengths of the title compound in $\mathrm{CH}_{3} \mathrm{OH}$ solution listed in Table 4. The UV-Vis absorption spectrum of methanol solution for the ligand shows strong bands around 357, 290 and $240 \mathrm{~nm}$. After complexed with $\mathrm{Cu}(\mathrm{II})$, these bands red shift to 415, 297 and $242 \mathrm{~nm}$. The observed band at $415 \mathrm{~nm}$ in $\mathrm{CH}_{3} \mathrm{OH}$ solution was compared with the theoretical data $412 \mathrm{~nm}$ in gas phase and $405 \mathrm{~nm}$ in $\mathrm{CH}_{3} \mathrm{OH}$ solution for M062X theoretical level. The band was defined as $\mathrm{HOMO} \rightarrow \mathrm{LUMO}(\alpha), \mathrm{HOMO} \rightarrow \mathrm{LUMO}+1(\alpha)$ and $\mathrm{HOMO} \rightarrow \mathrm{LUMO}+2(\beta)$ and $\mathrm{HOMO} \rightarrow \mathrm{LUMO}+3(\beta)$ was classified as LLCT transition. The experimental band at $297 \mathrm{~nm}$ in $\mathrm{CH}_{3} \mathrm{OH}$ solution was represented by state in $291 \mathrm{~nm}$ for M062X. The 
oscillator strength was calculated between 0.5464 , and was classified as $\mathrm{HOMO} \rightarrow \mathrm{LUMO}+2(\alpha), \quad \mathrm{HOMO} \rightarrow \mathrm{LUMO}+9(\alpha) \quad$ and $\mathrm{HOMO} \rightarrow \mathrm{LUMO}+4(\beta)$, $\mathrm{HOMO} \rightarrow \mathrm{LUMO}+11(\beta)$ transition. These states of oscillator strengths between 0.3418 were classified as LLCT transitions.

\section{4. Natural bond orbital analysis}

The second order perturbation theory of Fock matrix in the NBO analysis shows strong intramolecular interactions, the interaction energies of the $\mathrm{Cu}$ (II) center with coordination atoms are listed in Table 5. With M062X/LanL2DZ method, the interaction energy correspond to the transfer of electrons from LP (1) N20 and N25 to empty orbital of $\mathrm{Cu}(54)$ were found to be 187.6 and $183.3 \mathrm{~kJ} \mathrm{~mol}^{-1}$, respectively, for $\alpha$ spin state and 319.4 and $322.4 \mathrm{~kJ} \mathrm{~mol}^{-1}$ for $\beta$ spin state. Almost the same interaction energy was obtained for the interaction energy correspond to the transfer of electrons from LP (1) N56 and N57 to empty orbital of $\mathrm{Cu}(55)$. These values indicated that the there are strong interaction between center $\mathrm{Cu}(\mathrm{II})$ and lone pair of the $\mathrm{N}$ atom in bpy. The interaction energies correspond to the transfer of electrons from bpy to empty orbital of $\mathrm{Cu}(54)$ were found to be $86.9 \mathrm{~kJ} \mathrm{~mol}^{-1}$ for $\alpha$ spin state and $89.5 \mathrm{~kJ} \mathrm{~mol}^{-1}$ for $\beta$ spin state, while the interaction energies correspond to the transfer of electrons from bpy to empty orbital of $\mathrm{Cu}(55)$ were found to be $85.2 \mathrm{~kJ} \mathrm{~mol}^{-1}$ for $\alpha$ spin state and $75.5 \mathrm{~kJ} \mathrm{~mol}^{-1}$ for $\beta$ spin state. There are weakly interaction between $\mathrm{Cu}(54)$ and $\mathrm{Cu}(55)$, the interaction energies correspond to the transfer of electrons from $\mathrm{Cu}(54)$ to empty orbital of $\mathrm{Cu}(55)$ were found to be $29.1 \mathrm{~kJ} \cdot \mathrm{mol}^{-1}$ for $\alpha$ spin state and 35.4 $\mathrm{kJ} \cdot \mathrm{mol}^{-1}$ for $\beta$ spin state. With B3LYP/LanL2DZ and PBE1PBE/LanL2DZ methods, the calculated values of interaction energies are different, but the trend is consistent. Based on local block eigen vector of the one-particle density matrix, the hybridization and covalent effects for the title complex was analyzed. The bond orbital occupancies, contribution from parent NBO, the natural atomic hybrids were described in Table 6. For example, for C5-N9 bond, with B3LYP/LanL2DZ method, the bond was formed by interaction between a $\mathrm{sp}^{2.63}(27.56 \% \mathrm{~s}, 72.44 \% \mathrm{p})$ orbital centered on the $\mathrm{C} 5$ and a $\mathrm{sp}^{2.04}(32.95 \% \mathrm{~s}, 67.05 \% \mathrm{p})$ orbital on the N9 atom. The molecular orbital can be described as $\sigma \mathrm{CN}=0.3658\left(\mathrm{sp}^{2.63}\right) \mathrm{C}+0.6342\left(\mathrm{sp}^{2.04}\right) \mathrm{N}$. This shows a strong polarization directed toward the $\mathrm{N}$ atom.

\subsection{Thermodynamic Properties}

The temperature dependence of the thermodynamic properties heat capacity at 
constant pressure $(\mathrm{Cp})$, entropy $(\mathrm{S})$, enthalpy $(\mathrm{H})$ and Gibbs free energy $(\mathrm{G})$ for the title compound were also determined by B3LYP/LanL2DZ method and were listed in Table 9. It can be observed that these thermodynamic functions, $\mathrm{Cp}, \mathrm{S}$ and $\mathrm{H}$ are increasing, while $\mathrm{G}$ decreasing with temperature ranging from 100 to $1000 \mathrm{~K}$ due to the fact that the molecular vibrational intensities increase with temperature. The correlation equations between heat capacity, entropy, enthalpy and Gibbs free energy with temperatures were filled by quadratic formulas, and the corresponding fitting factors $\left(\mathrm{R}^{2}\right)$ for these thermodynamic properties are $0.99909,0.999234,0.99182$ and 0.99893, respectively. The corresponding fitting equations are as follows and the correlations graphs have are showed in Fig. 5.

$$
\begin{aligned}
& \mathrm{Cv}=3.1857+0.83344 \times \mathrm{T}-3.59263 \times 10^{-4} \times \mathrm{T}^{2} \\
& \mathrm{~S}=95.43554+0.87949 \times \mathrm{T}-2.63485 \times 10^{-4} \times \mathrm{T}^{2} \\
& \mathrm{H}=549.2091+0.09554 \times \mathrm{T}+2.11327 \times 10^{-4} \times \mathrm{T}^{2} \\
& \mathrm{G}=562.10937+-0.15203 \times \mathrm{T}-2.78164 \times 10^{-4} \times \mathrm{T}^{2}
\end{aligned}
$$

\section{Conclusions}

The

$$
\mathrm{Cu}(\mathrm{II})
$$

complex

with

(E)-9-ethyl-3-(2-(6-(4-methylpyridin-2-yl)pyridin-3-yl)vinyl)-9H-carbazole

$\mathrm{Cu}_{2}$ (emppc $\left.)_{2} \mathrm{Cl}_{2}\right] \mathrm{Cl}_{2}$, was synthesised and investigated. The most important results and conclusions can be summarized as follows:

(1) In the complex cation, $\mathrm{Cu}(\mathrm{II})$ is bonded to two $\mathrm{Cl}^{-}$ligand and two emppc ligands which coordinate through two bpy nitrogen atoms, forming $\mathrm{Cl}^{-}$bridged binuclear structure. The geometry around the copper atom can be described as a highly distorted tetrahedron.

(2) The detailed assignments of the experimental infrared spectrum of the title compound have been made on the basis of the theoretical calculations of the $\left[\mathrm{Cu}_{2}(\mathrm{emppc})_{2} \mathrm{Cl}_{2}\right]^{2+}$ cation using the unrestricted density functional B3LYP, PBE1PBE and M062X methods with LanL2DZ basis set. The calculated frequencies show good agreement with experiments, the calculated results overestimate the frequencies with errors 2.5-4.8\%, 3.0-6.9\% and 4.3-7.5\% for B3LYP, PBE1PBE and M062X, respectively.

(3) The UV-Vis absorption spectrum of methanol solution for the ligand shows strong bands around 357, 290 and $240 \mathrm{~nm}$. After complexed with $\mathrm{Cu}(\mathrm{II})$, these bands red shift to 415, 297 and $242 \mathrm{~nm}$.. The calculated absorbsion bands show good 
agreement with experiments.

(4) With NBO analysis, the calculated interaction energies of $\mathrm{Cu}(\mathrm{II})$ with ligand's atom $\mathrm{N}$ are between 183.3.7-200.0 $\mathrm{kJ} \cdot \mathrm{mol}^{-1}$ for $\alpha$ spin and 319.4-324.9 $\mathrm{kJ} \cdot \mathrm{mol}^{-1}$ for $\beta$ spin.

The results provided helpful information on the rational design of novel polynuclear $\mathrm{Cu}(\mathrm{II})$ complexes of bipy derivatives with the specific spectroscopic natures.

\section{Acknowledgment}

We thank the National Science Foundation of Educational Commission of Jiangsu Province of China (Nos.12KJA150004) for financial support. The natural science foundation of Jiangsu Province (Grant No. BK20131212) and Huaian key lab for photoelectric conversion and energy storage materials for financial support for this work. 


\section{References}

[1] E.C. Constable, Adv. Inorg. Chem. 34 (1989) 1-63.

[2] K. Nakamoto, J. Phys. Chem. 64 (1960) 1420-1425.

[3] S. Campagna; F. Puntoriero; F. Nastasi; G. Bergamini; V. Balzani. Top. Curr. Chem. 280(2007), 117-122.

[4] A. Juris; V. Balzani; F. Barigelletti; S. Campagna; P. Belser; A. Zelewsky. Coord. Chem. Rev. 1988, 84, 85.

[5] V. Diana; M. T. Luminita; F. Oscar; R Catalina; L. Francesc; J. Miguel. Polyhedron, 28(2009), 851-859.

[6] Y. Yu, Y. Wei, R. Broer, K. Wu. Inorg. Chem. Commu., 10(2007), 1289-1293.

[7] L.T. Cui, Y. F. Niu, J. Han, X.L. Zhao. J. Solid State Chem., 227(2015), 155-164.

[8] S. Helten, B. Sahoo, P. Müller, D. J. Müller, N. Klein, R. Grünker. Microporous and Mesoporous Materials, 216(2015), 42-50.

[9] P.C. Cheng, Y.C. Lo, W. Hsu, K. B. T., S.M. Liou, J.D. Chen. Polyhedron, 96(2015), 1-5.

[10] M. K. Nazeeruddin, A. Kay, I. Rodicio. J. Am. Chem. Soc, 115( 1993), 63826390.

[11] M. K. Nazeeruddin, F. D. Angelis, S. Fantacci. J. Am. Chem. Soc. 127(2005), $16835-16847$.

[12] J. Hawecker, J. M. Lehn, R. Ziessel, Helv. Chim. Acta 69(1986), 1990-1998.

[13] J.M. Smieja, C.P. Kubiak, Inorg. Chem. 49 (2010), 9283-9289.

[14] S. Sato, T. Morikawa, T. Kajino, O. Ishitani Angew. Chem. Int. Ed., 52(2013), 988-992.

[15] E.M. Goldys (Ed.), Fluorescence Applications in Biotechnology and Life Sciences, Wiley, Hoboken, 2009.

[16] C.A. Puckett, J.K. Barton, J. Am. Chem. Soc. 129 (2007) 46-47.

[17] Masayori Hagimori, Takashi Temma, Naoko Mizuyama, Takuhiro Uto,Yasuchika Yamaguchi, Yoshinori Tominaga, Takahiro Mukai, Hideo Saji Sensors and Actuators B 213 (2015) 45-52.

[18] J. M. Lehn, Supramolecular Chemistry, VCH, Weinheim, Germany, 1995;

[19] J.-M. Lehn, Comprehensive Supramolecular Chemistry, Pergamon Press, Oxford, 1996.

[20] H. Pruchnik, T. Lis, M. Latocha, A. Zielińska, F. P. Pruchnik. J. Organometal. 
Chem. 777(2015), 81-87.

[21] J. Zdravković, D. Poleti, J. Rogan, D. M. Minić Polyhedron, 80(2014), 256-264,

[22] Q.R. Cheng, H. Zhou, Z.Q. Pan, G.Y. Liao, Z.G. Xu Polyhedron, 81(2014), 668-674.

[23] J. Piromchom, N. Wannarit, J. Boonmak, K. Chainok, C. Pakawatchai, S. Youngme. Inorg. Chem. Commu., 44(2014), 111-113.

[24] Z. Jin, H. Zhao, X. Zhao, X. Yao, G. Zhu. Inorg. Chem. Commun., 46(2014), 329-334..

[25] V. Vo, Y. Kim, N. V. Minh, C. Seop Hong, S.J. Kim. Polyhedron, 28(2009), 1150-1154

[26] R. P. Catalin, R. M. Yoland., H. M. María, F. S. Delgado, P. Jorge, J. S., F. Lloret, M. Julve Polyhedron, 22(2003), 2111-2123.

[27] S. A. Barnett, N. R. Champness J. Solid State Chem., 178(2005), 2491-2510.

[28] A. J. Fletcher, K. M. Thomas, M. J. Rosseinsky. Coord. Chem. Rev., 246(2003), 145-168.

[29] A. Bousquet, H. Awada, R. C. Hiorns, C. D.Lartigau, L. Billon. Progress in Poly. Sci., 39(2014), 1847-1877.

[30] J. W. Costin, N. W. Barnett, S. W. Lewis. Talanta, 64(2004), 894-898.

[31] G. Vicentini, L.B. Zinner, J. Zukerman-Schpector, K. Zinner. Coord. Chem. Rev., 196(2000), 353-382.

[32] A. Wojciechowsk, J. Janczak, W. Zierkiewicz, A. Dylong, E. M. Jon. Polyhedron 85 (2015), 665-674.

[33] R.D. Antonio, E. L. Mart, E. P. Jesús, A. J. Mota, E. Colacio. Inorg. Chim. Acta, 385(2012), 73-80.

[34] B Manuel, R Thierry, L B Hubert. Canadian J. Chem., 75(1997), 318-325.

[35] A. Coruh, F. Yilmaz, B. Sengez, M. Kurt, M. Cinar, M. Karabacak, Struct. Chem. 22 (2011), 45-56.

[36] M. Rico, J. M. Orza, J. Morcillo, Spectrochim. Acta 21 (1965), 689-719.

[37] M.A. Palafox, G. Tardajos, A.G. Martines, V.K. Rastogi, D. Mishra, S.P. Ojha, W. Kiefer, Chem. Phys. 340 (2007) 17-31.

[38] M. Karabacak, E. Kose, M. Kurt, J. Raman Spectrosc. 41 (2010), 1085-1097.

[39] A. D. Becke, J. Chem. Phys. 98 (1993), 1372-1377.

[40] C. Adamo, V. Barone. J. Chem. Phys. 110 (1999), 6158-6169.

[41] Y. Zhao, D. G. Truhlar. J. Phys. Chem., 110 (2006), 5121-29. 
[42] R. D. Bach, M. N. Glukhovtsev, C. Gonzalez, M. Marquez, C. M. Estevez, A. G. Baboul, H. B. Schlegel, J. Phys. Chem. A 101(1997), 6092-6100.

[43] B. Machura, M. Wolff, M. Jaworska, P. Lodowski, E. Benoist, C. Carrayon, N. Saffon, R. Kruszynski, Z. Mazurak, J. Organomet. Chem. 696(2011), 3068-3075.

[44] S. Caglar, S. Demir, Z. Heren, O. Büyükgüngör, Polyhedron. 30(2011), 1389-1395.

[45] A.V. Jr, S. Záliš, Coord. Chem. Rev. 251(2007), 258-287.]

[46] HyperChem Pro., Release 6.03, Hypercube Inc., USA, 2000.

[47] N. M. OflBoyle, J. G. Vos, GaussSum1.0, Dublin City University, 2005.

[48] M. J. Frisch, G. W. Trucks, H. B. Schlegel, GAUSSIAN 09, Revision B.03, Gaussian, Inc., Pittsburgh PA, 2009.

[49] C. Jarmorski, M. E. Casida, D. R. Salahub, J. Chem. Phys. 104(1996), 5134-5147.

[50] G. Liu, L. L. Li, Y. S. Ren, H. X. Li , Z. G. Ren, Y. Z., J. P. Lang. Inorg. Chem. Commu. 12(2009), 563-565.

[51] E. Liu, Y. Z. Zhang, L. Li, C. Yang, J. C. Fettinger, G. Zhang. Polyhedron 99(2015), 223-229.

[52] Y. Wang, Y. Zhang, H. Ni, N. Meng, K. Ma, J. Zhao, D. Zhu. Spectrochimica Acta Part A, 135(2015), 296-306.

[53] M. K. Penney, C. Potter, M. A. Burroughs Jr., K. K. Klausmeyer. Polyhedron 102(2015), 207-215.

[54] İ. Kara, Y. Kara, A.Ö. Kiraz, R. Mammadov. Spectrochimica Acta Part A: Molecular and Biomolecular Spectroscopy 149(2015), 592-599.

[55] R. T. Ulahannan, C. Y. Panicker, H. T. Varghese, R. Musiol, J. Jampilek, C. Van Alsenoy, J. A. War, A. A. Al-Saadi. Spectrochim. Acta Part A: Molecular and Biomolecular Spectroscopy 151(2015), 335-349.

[56] D. Rajaraman, G. Sundararajan, A. Kamaraj, H. Saleem, K. Krishnasamy, Spectrochim. Acta Part A: Molecular and Biomolecular Spectroscopy 151(2015), $480-489$. 
Table 1 Optimized and experimental bond distances $(\AA)$ and bond angles $\left({ }^{\circ}\right)$ for the compound.

\begin{tabular}{|c|c|c|c|c|c|c|c|}
\hline Bond lenth & B3LYP & PBE1PBE & M062X & Bond angle & B3LYP & PBE1PBE & M062X \\
\hline $\mathrm{R}(1,2)$ & 1.4098 & 1.4014 & 1.3991 & $\mathrm{~A}(2,1,6)$ & 118.8 & 118.8 & 118.8 \\
\hline $\mathrm{R}(1,6)$ & 1.4037 & 1.4007 & 1.4029 & $\mathrm{~A}(7,8,9)$ & 109.2 & 109.1 & 109.1 \\
\hline $\mathrm{R}(2,3)$ & 1.4148 & 1.4108 & 1.4135 & $\mathrm{~A}(9,8,13)$ & 129.6 & 129.6 & 129.5 \\
\hline $\mathrm{R}(3,4)$ & 1.4075 & 1.4011 & 1.3999 & $\mathrm{~A}(5,9,8)$ & 108.8 & 108.9 & 108.8 \\
\hline $\mathrm{R}(4,5)$ & 1.4043 & 1.3989 & 1.4005 & $\mathrm{~A}(21,20,54)$ & 113.3 & 113.0 & 112.9 \\
\hline$R(5,6)$ & 1.4276 & 1.421 & 1.4198 & $\mathrm{~A}(21,24,25)$ & 115.3 & 115.1 & 115.1 \\
\hline $\mathrm{R}(5,9)$ & 1.4137 & 1.4063 & 1.4059 & $\mathrm{~A}(24,25,54)$ & 114.0 & 113.5 & 113.2 \\
\hline $\mathrm{R}(6,7)$ & 1.4615 & 1.4536 & 1.4569 & $\mathrm{~A}(20,54,25)$ & 81.6 & 82.9 & 83.3 \\
\hline $\mathrm{R}(7,8)$ & 1.4419 & 1.4361 & 1.4346 & $\mathrm{~A}(25,54,109)$ & 98.1 & 97.2 & 96.5 \\
\hline $\mathrm{R}(8,9)$ & 1.3866 & 1.3781 & 1.3801 & $\mathrm{~A}(25,54,110)$ & 158.8 & 163.9 & 168.4 \\
\hline $\mathrm{R}(8,13)$ & 1.4116 & 1.4066 & 1.4065 & $\mathrm{~A}(109,54,110)$ & 89.5 & 86.7 & 85.2 \\
\hline $\mathrm{R}(9,14)$ & 1.4748 & 1.4637 & 1.4642 & $\mathrm{~A}(56,55,57)$ & 81.6 & 82.8 & 83.4 \\
\hline $\mathrm{R}(10,11)$ & 1.4264 & 1.4188 & 1.4148 & $\mathrm{~A}(56,55,109)$ & 98.0 & 97.9 & 96.9 \\
\hline $\mathrm{R}(11,12)$ & 1.4322 & 1.4273 & 1.4254 & $\mathrm{~A}(56,55,110)$ & 159.5 & 163.7 & 169.3 \\
\hline $\mathrm{R}(11,16)$ & 1.4546 & 1.4456 & 1.452 & $\mathrm{~A}(57,55,109)$ & 158.4 & 162.3 & 168.3 \\
\hline $\mathrm{R}(12,13)$ & 1.3951 & 1.3893 & 1.3909 & $\mathrm{~A}(109,55,110)$ & 89.4 & 86.2 & 85.1 \\
\hline $\mathrm{R}(14,15)$ & 1.5436 & 1.5335 & 1.536 & $\mathrm{~A}(55,56,62)$ & 113.3 & 113.0 & 112.8 \\
\hline $\mathrm{R}(16,17)$ & 1.3718 & 1.3698 & 1.3651 & $\mathrm{~A}(55,57,63)$ & 113.9 & 113.5 & 113.2 \\
\hline $\mathrm{R}(17,18)$ & 1.457 & 1.4459 & 1.4512 & $\mathrm{~A}(55,57,66)$ & 126.1 & 126.4 & 126.6 \\
\hline $\mathrm{R}(18,19)$ & 1.4226 & 1.4193 & 1.4183 & $\mathrm{~A}(56,58,59)$ & 122.9 & 122.9 & 122.8 \\
\hline $\mathrm{R}(18,23)$ & 1.4239 & 1.4203 & 1.4185 & $\mathrm{~A}(56,58,75)$ & 116.2 & 116.5 & 116.9 \\
\hline $\mathrm{R}(19,20)$ & 1.3467 & 1.3415 & 1.3448 & $\mathrm{~A}(59,58,75)$ & 120.8 & 120.7 & 120.3 \\
\hline $\mathrm{R}(20,21)$ & 1.3693 & 1.3659 & 1.3664 & $\mathrm{D}(19,20,54,110)$ & -21.6 & -17.3 & -12.6 \\
\hline $\mathrm{R}(20,54)$ & 2.0398 & 1.9938 & 1.9884 & $\mathrm{D}(24,25,54,109)$ & 160.4 & 165.3 & 169.7 \\
\hline $\mathrm{R}(21,22)$ & 1.4105 & 1.4041 & 1.4006 & $\mathrm{D}(20,54,109,55)$ & -119.7 & -110.6 & -104.4 \\
\hline $\mathrm{R}(21,24)$ & 1.4784 & 1.466 & 1.4739 & $\mathrm{D}(25,54,109,55)$ & 152.5 & 160.2 & 167.0 \\
\hline $\mathrm{R}(22,23)$ & 1.3967 & 1.3908 & 1.394 & $\mathrm{D}(110,54,109,55)$ & -7.7 & -4.1 & -1.5 \\
\hline $\mathrm{R}(24,25)$ & 1.3698 & 1.3657 & 1.3664 & $\mathrm{D}(20,54,110,55)$ & 169.4 & 169.8 & 170.9 \\
\hline $\mathrm{R}(24,29)$ & 1.4071 & 1.4012 & 1.3979 & $\mathrm{D}(25,54,110,55)$ & -103.8 & -100.5 & -97.5 \\
\hline $\mathrm{R}(25,26)$ & 1.3557 & 1.3524 & 1.3548 & $\mathrm{D}(109,54,110,55)$ & 7.7 & 4.1 & 1.5 \\
\hline $\mathrm{R}(25,54)$ & 2.0269 & 1.9844 & 1.9836 & $\mathrm{D}(109,55,56,58)$ & -21.8 & -18.5 & -13.1 \\
\hline $\mathrm{R}(26,27)$ & 1.3998 & 1.3928 & 1.3933 & $\mathrm{D}(109,55,56,62)$ & 157.6 & 161.6 & 167.9 \\
\hline $\mathrm{R}(27,28)$ & 1.4156 & 1.4114 & 1.4104 & $\mathrm{D}(110,55,56,58)$ & 88.5 & 85.2 & 87.6 \\
\hline $\mathrm{R}(28,29)$ & 1.4108 & 1.405 & 1.4065 & $\mathrm{D}(109,55,57,63)$ & -90.9 & -93.8 & -91.3 \\
\hline $\mathrm{R}(28,46)$ & 1.5108 & 1.5015 & 1.5051 & $\mathrm{D}(109,55,57,66)$ & 91.0 & 88.1 & 87.2 \\
\hline $\mathrm{R}(54,109)$ & 2.4076 & 2.3762 & 2.3728 & $\mathrm{D}(110,55,57,63)$ & 159.0 & 163.2 & 170.3 \\
\hline $\mathrm{R}(54,110)$ & 2.402 & 2.3721 & 2.3722 & $\mathrm{D}(110,55,57,66)$ & -19.2 & -14.9 & -11.2 \\
\hline $\mathrm{R}(55,56)$ & 2.0402 & 2 & 1.9882 & $\mathrm{D}(56,55,109,54)$ & 168.5 & 168.3 & 170.9 \\
\hline $\mathrm{R}(55,57)$ & 2.0279 & 1.9891 & 1.983 & $\mathrm{D}(57,55,109,54)$ & -104.1 & -100.7 & -98.1 \\
\hline $\mathrm{R}(55,109)$ & 2.4038 & 2.3846 & 2.3724 & $\mathrm{D}(56,55,110,54)$ & -119.4 & -109.3 & -103.3 \\
\hline $\mathrm{R}(55,110)$ & 2.4087 & 2.3885 & 2.375 & $\mathrm{D}(57,55,110,54)$ & 152.1 & 158.7 & 166.9 \\
\hline$R(56,58)$ & 1.3466 & 1.3413 & 1.3444 & $\mathrm{D}(109,55,110,54)$ & -7.7 & -4.1 & -1.5 \\
\hline
\end{tabular}


Table 2 Experimental and calculated IR vibrational frequencies $\left(\mathrm{cm}^{-1}\right)$ and intensity of the title compound.

\begin{tabular}{|c|c|c|c|c|c|c|c|c|c|c|}
\hline & B3LYP & & & BE1PBI & & & M06X & & & \\
\hline $\begin{array}{l}\text { Wavel } \\
\text { ength }\end{array}$ & $\begin{array}{l}\text { Intensi } \\
\text { ty }\end{array}$ & $\begin{array}{l}\text { Scaled } \\
\text { wavel } \\
\text { ength }\end{array}$ & $\begin{array}{l}\text { Wavel } \\
\text { ength }\end{array}$ & $\begin{array}{l}\text { Intensi } \\
\text { ty }\end{array}$ & $\begin{array}{l}\text { Scaled } \\
\text { wavel } \\
\text { ength }\end{array}$ & $\begin{array}{l}\text { Wavel } \\
\text { ength }\end{array}$ & $\begin{array}{l}\text { Intensi } \\
\text { ty }\end{array}$ & $\begin{array}{l}\text { Scaled } \\
\text { wavel } \\
\text { ength }\end{array}$ & $\begin{array}{l}\text { Exp. } \\
\text { IR }\end{array}$ & Assign.(PED) ${ }^{\mathrm{a}}$ \\
\hline 550 & 4.4 & 531 & 557 & 1.6 & 530 & 560 & 27.3 & 531 & 536 & $\begin{array}{l}\delta C C C(\text { carbazole })(11) \\
\tau \mathrm{CCC}(\text { Carbazole })(41)\end{array}$ \\
\hline 571 & 23.1 & 551 & 579 & 47.9 & 551 & 589 & 11.5 & 558 & 557 & $\begin{array}{c}\delta \mathrm{CCC}(\text { carbazole })(12)+\tau \mathrm{CCC} \\
(\text { Carbazole }) \\
(35)+\omega \mathrm{CC}(\text { Carbazole }) \mathrm{H}(44)\end{array}$ \\
\hline 652 & 21.0 & 629 & 653 & 21.1 & 621 & 654 & 20.6 & 620 & 627 & $\begin{array}{l}\tau \mathrm{CCC}(\text { Carbazole })(35) \\
\omega \mathrm{CC}(\text { Carbazole }) \mathrm{H}(41)\end{array}$ \\
\hline 773 & 10.8 & 746 & 782 & 8.2 & 744 & 784 & 21.3 & 743 & 748 & $\begin{array}{c}\delta C C C(\text { bpy })(14)+ \\
\delta C C C(\text { carbazole })(40)\end{array}$ \\
\hline 850 & 32.4 & 820 & 854 & 36.3 & 813 & 862 & 40.0 & 817 & 829 & $\omega \mathrm{C}($ carbazole $) \mathrm{H}(81))$ \\
\hline 885 & 3.4 & 854 & 890 & 111.5 & 847 & 898 & 8.9 & 851 & 853 & $\omega \mathrm{C}($ carbazole $) \mathrm{H}(76)$ \\
\hline 914 & 4.8 & 882 & 918 & 121.4 & 874 & 921 & 10.4 & 873 & 880 & $\begin{array}{c}\tau \mathrm{C} 58(60) \mathrm{C} 59 \mathrm{C} 74 \mathrm{H}(13)+ \\
\tau \mathrm{C} 59 \mathrm{C} 74 \mathrm{C} 79 \mathrm{H}(10)+ \\
\tau \mathrm{C} 82 \mathrm{C} 79 \mathrm{C} 74 \mathrm{H}(16)\end{array}$ \\
\hline 960 & 15.4 & 926 & 979 & 19.4 & 932 & 980 & 14.8 & 929 & 934 & $\begin{array}{c}v \mathrm{C} 14 \mathrm{C} 15(33)+\delta \mathrm{C} 14 \mathrm{C} 15 \mathrm{H}(2 \\
2)+\tau \mathrm{HC} 14 \mathrm{C} 15 \mathrm{H}(8)\end{array}$ \\
\hline 999 & 9.2 & 964 & 1002 & 9.5 & 954 & 1014 & 12.5 & 961 & 969 & $\tau \mathrm{HCC}($ Carbazole $) \mathrm{H}(77)$ \\
\hline 1075 & 18.2 & 1037 & 1094 & 11.7 & 1041 & 1099 & 17.7 & 1042 & 1026 & 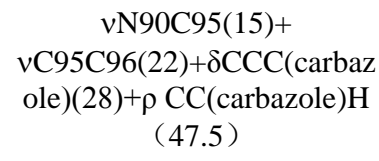 \\
\hline 1133 & 15.4 & 1093 & 1160 & 24.2 & 1104 & 1166 & 266.7 & 1105 & 1085 & $\begin{array}{c}\rho \mathrm{CC}(\text { Carbazole }) \mathrm{H}(24)+\text { ring } \\
\text { breath }(\text { carbazole })(17)+ \\
\tau \mathrm{HC} 95 \mathrm{C} 96 \mathrm{H}(22)\end{array}$ \\
\hline 1164 & 62.6 & 1123 & 1179 & 127.7 & 1122 & 1183 & 22.0 & 1121 & 1123 & $\begin{array}{c}\rho \mathrm{cc}(\text { bpy }) \mathrm{H}(25)+\rho \\
\mathrm{CC}(\text { carbazole }) \mathrm{H}(20)+\tau \mathrm{HC} 95 \\
\mathrm{C} 96 \mathrm{H}(12)\end{array}$ \\
\hline 1190 & 74.5 & 1148 & 1202 & 568.4 & 1144 & 1208 & 239.0 & 1145 & 1155 & $\begin{array}{c}\rho \mathrm{CC}(\text { bpy }) \mathrm{H}(25)+\rho \\
\mathrm{CC}(\text { carbazole }) \mathrm{H}(20.3) \\
+\tau \mathrm{HC} 95 \mathrm{C} 96 \mathrm{H}(12)\end{array}$ \\
\hline 1221 & 188.1 & 1178 & 1236 & 176.4 & 1176 & 1233 & 543.0 & 1169 & 1179 & $\begin{array}{c}\nu \mathrm{CC}(\text { bpy })(18)+ \\
\rho \mathrm{cc}(\text { bpy }) \mathrm{H}(17)+\rho \\
\mathrm{CC}(\text { carbazole }) \mathrm{H}(48)\end{array}$ \\
\hline 1262 & 137.5 & 1218 & 1282 & 69.4 & 1220 & 1279 & 142.5 & 1212 & 1217 & $\begin{array}{c}v \mathrm{CC}(\text { carbazole })(15)+ \\
\omega c c(\text { carbazole }) \mathrm{H}(12)+\rho \\
\mathrm{CC}(\text { bpy }) \mathrm{H}(35)\end{array}$ \\
\hline 1283 & 110.5 & 1238 & 1299 & 479.0 & 1236 & 1297 & 6.5 & 1230 & 1235 & $\begin{array}{c}v \mathrm{CC}(\text { bpy })(14)+ \\
\rho \mathrm{C} 16 \mathrm{C} 17 \mathrm{H}(41.8)+\rho \\
\mathrm{CC}(\mathrm{bpy}) \mathrm{H}(20)\end{array}$ \\
\hline 1330 & 174.5 & 1283 & 1350 & 377.0 & 1285 & 1349 & 41.3 & 1279 & 1287 & $\begin{array}{c}\text { C63N57 }(10) v \mathrm{CC}(\text { bpy })(14)+ \\
\text { CC }(\text { Carbazole })(12)+ \\
\rho C C 79 \mathrm{H}(16) \rho \\
\mathrm{C}(\text { carbazole }) \mathrm{H}(40)\end{array}$ \\
\hline 1382 & 74.4 & 1334 & 1409 & 135.9 & 1341 & 1402 & 44.5 & 1329 & 1335 & $\begin{array}{c}v \mathrm{CC}(\mathrm{bpy})(12)+\rho \mathrm{N} 9 \mathrm{C} 14 \mathrm{H} \\
\quad(10)+\rho \mathrm{CC}(\mathrm{bpy}) \mathrm{H}(40)\end{array}$ \\
\hline 1438 & 85.7 & 1388 & 1448 & 11.3 & 1378 & 1451 & 19.5 & 1376 & 1389 & $\begin{array}{c}\nu \mathrm{CC}(\text { carbazole })(11)+\rho \\
\mathrm{C}(\text { bpy }) \mathrm{H}(27) \\
\rho \mathrm{C} 74 \mathrm{C} 79 \mathrm{H}(37)\end{array}$ \\
\hline 1475 & 61.9 & 1423 & 1501 & 447.6 & 1428 & 1500 & 263.7 & 1422 & 1413 & $\begin{array}{c}\nu \mathrm{CC}(\text { carbazole })(13)+\rho \\
\mathrm{C}(\text { carbazole }) \mathrm{H}(69)\end{array}$ \\
\hline 1527 & 92.3 & 1474 & 1547 & 36.2 & 1472 & 1551 & 11.0 & 1470 & 1475 & $\begin{array}{l}\mathrm{CC}(\text { carbazole })(25), \rho \\
\mathrm{C}(\text { carbazole }) \mathrm{H}(43)\end{array}$ \\
\hline 1544 & 77.5 & 1490 & 1559 & 34.6 & 1484 & 1569 & 53.8 & 1487 & 1491 & $\begin{array}{c}\omega \mathrm{HC} 14 \mathrm{C} 15 \mathrm{H}(45), \\
\omega \mathrm{C} 5(8) \mathrm{N} 9 \mathrm{C} 14 \mathrm{H}(18)\end{array}$ \\
\hline 1604 & 115.9 & 1548 & 1635 & 61.9 & 1556 & 1646 & 257.3 & 1560 & 1558 & $\begin{array}{c}\nu \mathrm{CC}(\mathrm{bpy})(17), \\
v \mathrm{CC}(\text { carbazole })(19), \rho \delta \mathrm{CC}(\mathrm{b} \\
\text { py)H(12) }\end{array}$ \\
\hline
\end{tabular}




\begin{tabular}{|c|c|c|c|c|c|c|c|c|c|c|}
\hline & & & & & & & & & & $\delta \mathrm{CC}($ carbazole $) \mathrm{H}(14)$ \\
\hline 1650 & 224.2 & 1592 & 1683 & 254.8 & 1602 & 1694 & 174.5 & 1606 & 1588 & $\begin{array}{c}\nu \mathrm{CC}(\mathrm{bpy})(38), \rho \mathrm{CC}(\mathrm{bpy}) \mathrm{H}(4 \\
9)\end{array}$ \\
\hline 1672 & 2848.3 & 1613 & 1707 & 4459.6 & 1624 & 1723 & 16.6 & 1633 & 1615 & $\begin{array}{l}\text { vCC (carbazole })(31)+ \\
\rho H C C(\text { carbazole })(34)\end{array}$ \\
\hline 3051 & 8.2 & 2944 & 3079 & 3.4 & 2930 & 3076 & 18.4 & 2916 & 2930 & vC46H(100) \\
\hline 3090 & 314.0 & 2982 & 3113 & 364.9 & 2962 & 3111 & 36.0 & 2949 & 2976 & vC14H(96) \\
\hline 3170 & 99.4 & 3059 & 3199 & 6.3 & 3044 & 3200 & 7.0 & 3034 & 3068 & vC16(17)H (97) \\
\hline
\end{tabular}

${ }^{a}$ Abbreviation/symbols: $v$, stretching; $\delta$, bending in-plane; $\tau$, torsion; $\omega$, wagging out-of-plane; $\rho$, wagging in-plane; PED: potential energy distribution 
Table 3 The energy levels (eV) of the frontier orbitals of the title compound calculated with M062X/LanL2DZ theoretical level.

\begin{tabular}{|c|c|c|c|c|c|c|c|c|c|c|c|c|}
\hline Orbital & $\begin{array}{l}\alpha \text { spin } \\
\mathrm{E}(\mathrm{eV})\end{array}$ & $\mathrm{Cu}$ & $\mathrm{Cl}$ & $\begin{array}{l}\text { carba } \\
\text { zole }\end{array}$ & bpy & $\begin{array}{l}\text { C16=C17 } \\
(\mathrm{C} 74=\mathrm{C} 79)\end{array}$ & $\begin{array}{l}\beta \text { spin } \\
E(e V)\end{array}$ & $\mathrm{Cu}$ & $\mathrm{Cl}$ & $\begin{array}{l}\text { carbazo } \\
\text { le }\end{array}$ & bpy & $\begin{array}{l}\mathrm{C} 16=\mathrm{C} 17 \\
(\mathrm{C} 74=\mathrm{C} 79)\end{array}$ \\
\hline LUMO+6 & -4.256 & 0.16 & 0.00 & 0.27 & 96.80 & 1.94 & -4.775 & 1.53 & 0.11 & 25.37 & 68.75 & 3.76 \\
\hline LUMO+5 & -4.783 & 0.30 & 0.02 & 12.18 & 81.90 & 5.33 & -5.134 & 1.86 & 0.14 & 2.32 & 92.97 & 2.23 \\
\hline LUMO+4 & -4.804 & 1.74 & 0.09 & 2.44 & 92.78 & 2.47 & -5.165 & 0.19 & 0.03 & 89.05 & 8.56 & 1.89 \\
\hline LUMO+3 & -5.136 & 1.54 & 0.15 & 35.25 & 56.65 & 5.81 & -6.335 & 4.29 & 1.08 & 5.19 & 81.67 & 6.74 \\
\hline LUMO+2 & -5.167 & 0.13 & 0.02 & 91.81 & 6.80 & 1.01 & -6.372 & 0.85 & 0.13 & 21.78 & 53.71 & 23.16 \\
\hline LUMO+1 & -6.378 & 1.81 & 3.13 & 4.94 & 85.15 & 6.71 & -7.557 & 57.73 & 12.57 & 0.36 & 28.00 & 0.44 \\
\hline LUMO & -6.408 & 0.48 & 0.07 & 25.33 & 46.42 & 27.43 & -7.581 & 0.90 & 0.28 & 71.96 & 11.66 & 14.31 \\
\hline HOMO & -9.617 & 0.01 & 0.01 & 80.91 & 8.1 & 9.97 & -9.618 & 0.01 & 0.00 & 80.68 & 8.33 & 9.97 \\
\hline HOMO-1 & -9.670 & 0.04 & 0.02 & 97.31 & 1.1 & 1.4 & -9.670 & 9.53 & 3.22 & 79.50 & 6.09 & 1.37 \\
\hline HOMO-2 & -10.185 & 52.73 & 17.51 & 0.11 & 28.66 & 0.13 & -10.185 & 47.87 & 15.91 & 9.27 & 25.98 & 0.33 \\
\hline HOMO-3 & -10.286 & 0.02 & 0.02 & 67.38 & 15.29 & 17.15 & -10.286 & 0.04 & 0.02 & 67.84 & 14.97 & 16.99 \\
\hline HOMO-4 & -11.045 & 2.04 & 0.27 & 43.02 & 35.75 & 18.54 & -11.045 & 7.36 & 1.42 & 44.31 & 35.30 & 11.19 \\
\hline HOMO-5 & -11.129 & 0.69 & 0.39 & 57.73 & 28.18 & 12.59 & -11.129 & 0.59 & 0.41 & 56.46 & 28.81 & 13.31 \\
\hline HOMO-6 & -12.210 & 67.99 & 13.51 & 5.3 & 12.37 & 0.21 & -12.209 & 68.82 & 14.35 & 3.85 & 12.03 & 0.41 \\
\hline
\end{tabular}


Table 4 Experimental and calculated absorption wavelengths, energies and oscillator strengths of the title compound in $\mathrm{CH}_{3} \mathrm{OH}$ solution

\begin{tabular}{|c|c|c|c|c|c|c|c|c|c|}
\hline $\begin{array}{l}\text { Gas } \\
\text { OrbitalOcc. }\end{array}$ & $\begin{array}{l}\text { Energy } \\
(\mathrm{eV})\end{array}$ & $\begin{array}{l}\text { Wavelen } \\
\text { gth }(\mathrm{nm})\end{array}$ & Os. & $\begin{array}{l}\mathrm{CH}_{3} \mathrm{OH} \text { solution } \\
\text { Orbital Occ. }\end{array}$ & Energy & $\begin{array}{l}\text { Wavelen } \\
\text { gth }\end{array}$ & Os. & $\exp$ & Assign \\
\hline $\operatorname{HOMO}(\alpha) \rightarrow \operatorname{LUMO}+1(\alpha)(0.5914)$ & 2.5312 & 489.83 & 0.9033 & & & & & & $\begin{array}{l}\text { LLCT } \\
\text { MLCT }\end{array}$ \\
\hline \multicolumn{10}{|l|}{$\operatorname{HOMO}-5(\beta) \rightarrow \operatorname{LUMO}(\beta)(0.4882)$} \\
\hline \multicolumn{10}{|l|}{$\operatorname{HOMO}(\beta) \rightarrow \mathrm{LUMO}+3(\beta)(0.5717)$} \\
\hline $\operatorname{HOMO}-2(\alpha) \rightarrow \operatorname{LUMO}(\alpha)(-0.2713)$ & 3.0084 & 412.13 & 0.1109 & $\operatorname{HOMO}(\alpha) \rightarrow \operatorname{LUMO}(\alpha)(-0.4456)$ & 3.0599 & 405.19 & 1.4508 & 415 & \multirow{4}{*}{$\begin{array}{l}\text { MLCT } \\
\text { LLCT }\end{array}$} \\
\hline $\operatorname{HOMO}-13(\beta) \rightarrow \operatorname{LUMO}(\beta)(0.6792)$ & & & & $\operatorname{HOMO}(\alpha) \rightarrow \mathrm{LUMO}+1(\alpha)(0.4651)$ & & & & & \\
\hline \multirow[t]{2}{*}{ HOMO $-1(\beta) \rightarrow$ LUMO $+3(\beta)(0.2290)$} & & & & $\operatorname{HOMO}(\beta) \rightarrow \mathrm{LUMO}+2(\beta)(-0.4604)$ & & & & & \\
\hline & & & & $\mathrm{HOMO}(\beta) \rightarrow \mathrm{LUMO}+3(\beta)(0.4518)$ & & & & & \\
\hline $\mathrm{HOMO}-3(\alpha) \rightarrow \mathrm{LUMO}+1(\alpha)(0.4339)$ & 3.8478 & 322.22 & 0.3004 & & & & & & $\begin{array}{l}\text { LLCT } \\
\text { MLCT }\end{array}$ \\
\hline \multicolumn{10}{|l|}{ HOMO- $6(\beta) \rightarrow$ LUMO $+2(\beta)(0.1836)$} \\
\hline \multicolumn{10}{|l|}{ HOMO $-3(\beta) \rightarrow$ LUMO $+3(\beta)(0.4316)$} \\
\hline $\mathrm{HOMO}-24(\beta) \rightarrow \mathrm{LUMO}+1(\beta)(-0.1786)$ & 3.9566 & 313.36 & 0.1639 & $\operatorname{HOMO}(\alpha) \rightarrow \mathrm{LUMO}+2(\alpha)(-0.2686)$ & 4.2659 & 290.64 & 0.5464 & 297 & LLCT \\
\hline \multirow[t]{4}{*}{ HOMO-15( $\beta) \rightarrow$ LUMO+1 $(\beta)(0.8591)$} & & & & $\operatorname{HOMO}(\alpha) \rightarrow \operatorname{LUMO}+9(\alpha)(0.2637)$ & & & & & \\
\hline & & & & $\operatorname{HOMO}(\beta) \rightarrow \mathrm{LUMO}+4(\beta)(-0.2747)$ & & & & & \\
\hline & & & & $\operatorname{HOMO}(\beta) \rightarrow \mathrm{LUMO}+11(\beta)(0.2836)$ & & & & & \\
\hline & & & & $\operatorname{HOMO}-4(\alpha) \rightarrow \operatorname{LUMO}(\alpha)(-0.2323)$ & 4.4691 & 277.43 & 0.3418 & & LLCT \\
\hline
\end{tabular}




\begin{tabular}{|c|c|c|c|c|c|c|c|c|c|}
\hline & & & & HOMO-4( $\alpha) \rightarrow$ LUMO+1( $\alpha)(-0.2301)$ & & & & & \\
\hline & & & & $\operatorname{HOMO}-19(\beta) \rightarrow \operatorname{LUMO}(\beta)(0.4059)$ & & & & & \\
\hline & & & & HOMO-4( $\beta) \rightarrow$ LUMO+3( $\beta)(-0.2343)$ & & & & & \\
\hline HLMO-1 $(\alpha) \rightarrow$ LUMO+5( $\alpha)(-0.3087)$ & 4.9660 & 249.66 & 0.1672 & $\mathrm{HOMO}-3(\alpha) \rightarrow \mathrm{LUMO}+6(\alpha)(0.2845)$ & 4.8155 & 257.47 & 0.3679 & & LLCT \\
\hline HOMO-1 $(\alpha) \rightarrow$ LUMO $+13(\alpha)(0.3775)$ & & & & $\operatorname{HOMO}-25(\beta) \rightarrow \operatorname{LUMO}(\beta)(0.3261)$ & & & & & \\
\hline HOMO-1 $(\beta) \rightarrow$ LUMO+8( $\beta)(-0.2968)$ & & & & $\mathrm{HOMO}-3(\beta) \rightarrow \mathrm{LUMO}+8(\beta)(0.2568)$ & & & & & \\
\hline \multicolumn{10}{|l|}{ HOMO- $1(\beta) \rightarrow$ LUMO $+13(\beta)(0.3727)$} \\
\hline HOMO- $1(\alpha) \rightarrow$ LUMO $+6(\alpha)(0.4352)$ & 5.0048 & 247.73 & 0.2135 & $\operatorname{HOMO}-32(\beta) \rightarrow \operatorname{LUMO}(\beta)(-0.3179)$ & 5.0449 & 245.76 & 0.3295 & 242 & LLCT \\
\hline HOMO-1 $(\alpha) \rightarrow$ LUMO $+12(\alpha)(0.2424)$ & & & & HOMO-26( $\beta) \rightarrow$ LUMO+1( $\beta)(0.3771)$ & & & & & \\
\hline HOMO- $1(\beta) \rightarrow$ LUMO+6( $\beta)(0.3259)$ & & & & HOMO-2( $\beta) \rightarrow$ LUMO $+10(\beta)(-0.1855)$ & & & & & \\
\hline
\end{tabular}


Table 5 Interaction energies ( $\mathrm{kJ} / \mathrm{mol})$ of $\mathrm{Co}(\mathrm{II})$ with ligands

\begin{tabular}{lllllll}
\hline & B3LYP & & M062X & \multicolumn{3}{c}{ PBE1PBE } \\
& $\alpha$ & $\beta$ & $\alpha$ & $\beta$ & $\alpha$ & $\beta$ \\
$\mathrm{N}(20)-\mathrm{Cu}(54)$ & 125.3 & 132.1 & 187.6 & 319.4 & 306.7 & 262.8 \\
$\mathrm{~N}(25)-\mathrm{Cu}(54)$ & 135.1 & 138.0 & 183.3 & 322.4 & 262.5 & 268.9 \\
$\mathrm{~N}(56)-\mathrm{Cu}(55)$ & 124.8 & 131.3 & 187.3 & 322.0 & 173.2 & 195.6 \\
$\mathrm{~N}(57)-\mathrm{Cu}(55)$ & 132.0 & 136.9 & 200.0 & 324.9 & 178.6 & 207.0 \\
$\mathrm{Cl}(109)-\mathrm{Cu}(54)$ & 198.9 & 211.5 & 250.2 & 332.6 & 228.3 & 293.6 \\
$\mathrm{Cl}(109)-\mathrm{Cu}(55)$ & 196.9 & 223.8 & 248.0 & 333.6 & 212.9 & 240.3 \\
$\mathrm{Cl}(110)-\mathrm{Cu}(54)$ & 194.0 & 184.1 & 252.4 & 332.7 & 223.6 & 297.2 \\
$\mathrm{Cl}(110)-\mathrm{Cu}(55)$ & 199.5 & 185.6 & 250.2 & 332.7 & 221.4 & 266.8 \\
$\mathrm{Cu}(54)-\mathrm{Cu}(55)$ & 11.0 & 19.5 & 29.1 & 35.4 & 27.8 & 15.0 \\
$\mathrm{Cu}(55)-\mathrm{Cu}(54)$ & 11.1 & 21.5 & 29.3 & 35.4 & 26.0 & 15.7 \\
$\mathrm{bpy}-\mathrm{Cu}(54)$ & 75.4 & 75.7 & 86.9 & 89.5 & 95.7 & 96.4 \\
$\mathrm{bpy}-\mathrm{Cu}(55)$ & 76.6 & 76.2 & 85.2 & 75.5 & 96.4 & 97.4
\end{tabular}

Table 6 Bond orbital analysis of title compound with B3LYP/LanL2DZ level of theory

\begin{tabular}{|c|c|c|c|c|c|c|}
\hline \multirow[t]{2}{*}{ Bond } & \multirow[t]{2}{*}{ Occupancy } & \multirow[t]{2}{*}{ Atom } & \multirow{2}{*}{$\begin{array}{l}\text { Contribution } \\
\text { from parent } \\
\mathrm{NBO}(\%)\end{array}$} & \multicolumn{2}{|c|}{$\begin{array}{l}\text { Atomic hybrid } \\
\text { contributions }(\%)\end{array}$} & \multirow[t]{2}{*}{ Hybrid } \\
\hline & & & & $\mathrm{s}$ & $\mathrm{p}$ & \\
\hline \multirow{2}{*}{$\mathrm{C} 1-\mathrm{C} 2$} & \multirow{2}{*}{0.98875} & $\mathrm{C} 1$ & 50.71 & 35.62 & 64.38 & $\mathrm{sp}^{1.81}$ \\
\hline & & $\mathrm{C} 2$ & 49.29 & 35.55 & 64.45 & $\mathrm{sp}^{1.81}$ \\
\hline \multirow[t]{2}{*}{$\mathrm{C} 1-\mathrm{C} 2$} & \multirow[t]{2}{*}{0.84881} & $\mathrm{C} 1$ & 48.77 & 0.00 & 100.00 & $\mathrm{sp}^{1.00}$ \\
\hline & & $\mathrm{C} 2$ & 51.23 & 0.00 & 100.00 & $\mathrm{sp}^{1.00}$ \\
\hline \multirow[t]{2}{*}{ C1-C6 } & \multirow[t]{2}{*}{0.98675} & $\mathrm{C} 1$ & 48.65 & 35.38 & 64.62 & $\mathrm{sp}^{1.83}$ \\
\hline & & C6 & 51.35 & 36.67 & 63.33 & $\mathrm{sp}^{1.73}$ \\
\hline \multirow[t]{2}{*}{$\mathrm{C} 2-\mathrm{C} 3$} & \multirow[t]{2}{*}{0.99000} & $\mathrm{C} 2$ & 49.93 & 35.17 & 64.83 & $\mathrm{sp}^{1.84}$ \\
\hline & & $\mathrm{C} 3$ & 50.07 & 35.37 & 64.63 & $\mathrm{sp}^{1.83}$ \\
\hline \multirow[t]{2}{*}{ C5-N9 } & \multirow{2}{*}{0.98908} & $\mathrm{C} 5$ & 36.58 & 27.56 & 72.44 & $\mathrm{sp}^{2.63}$ \\
\hline & & N9 & 63.42 & 32.95 & 67.05 & $\mathrm{sp}^{2.04}$ \\
\hline \multirow[t]{2}{*}{ N9-C14 } & \multirow[t]{2}{*}{0.99224} & N9 & 64.75 & 33.01 & 66.99 & $\mathrm{sp}^{2.03}$ \\
\hline & & $\mathrm{C} 14$ & 35.25 & 22.42 & 77.58 & $\mathrm{sp}^{3.46}$ \\
\hline \multirow[t]{2}{*}{ C8-N9 } & \multirow[t]{2}{*}{0.9896} & $\mathrm{C} 8$ & 37.10 & 28.79 & 71.21 & $\mathrm{sp}^{2.47}$ \\
\hline & & N9 & 62.90 & 33.92 & 66.08 & $\mathrm{sp}^{1.95}$ \\
\hline \multirow[t]{2}{*}{$\mathrm{C} 7-\mathrm{C} 8$} & \multirow[t]{2}{*}{0.97799} & C7 & 49.79 & 29.98 & 70.02 & $\mathrm{sp}^{2.34}$ \\
\hline & & C8 & 50.21 & 33.52 & 66.48 & $\mathrm{sp}^{1.98}$ \\
\hline \multirow[t]{2}{*}{$\mathrm{C} 7-\mathrm{C} 8$} & \multirow[t]{2}{*}{0.76033} & $\mathrm{C} 7$ & 54.14 & 0.00 & 100.00 & $\mathrm{sp}^{1.00}$ \\
\hline & & $\mathrm{C} 8$ & 45.86 & 0.00 & 100.00 & $\mathrm{sp}^{1.00}$ \\
\hline \multirow[t]{2}{*}{ C7C10 } & \multirow[t]{2}{*}{0.98652} & $\mathrm{C} 7$ & 50.50 & 36.75 & 63.25 & $\mathrm{sp}^{1.72}$ \\
\hline & & $\mathrm{C} 10$ & 49.50 & 36.19 & 63.81 & $\mathrm{sp}^{1.76}$ \\
\hline \multirow[t]{2}{*}{$\mathrm{C} 11-\mathrm{C} 16$} & \multirow[t]{2}{*}{0.98542} & $\mathrm{C} 11$ & 49.64 & 32.24 & 67.76 & $\mathrm{sp}^{2.10}$ \\
\hline & & $\mathrm{C} 16$ & 50.36 & 36.08 & 63.92 & $\mathrm{sp}^{1.77}$ \\
\hline \multirow[t]{2}{*}{$\mathrm{C} 16 \mathrm{C} 17$} & \multirow{2}{*}{0.98907} & $\mathrm{C} 16$ & 49.75 & 37.29 & 62.71 & $\mathrm{sp}^{1.68}$ \\
\hline & & $\mathrm{C} 17$ & 50.25 & 37.82 & 62.18 & $\mathrm{sp}^{1.64}$ \\
\hline \multirow[t]{2}{*}{ C16-C17 } & \multirow[t]{2}{*}{0.90387} & $\mathrm{C} 16$ & 43.89 & 0.01 & 99.99 & $\mathrm{sp}^{1.00}$ \\
\hline & & $\mathrm{C} 17$ & 56.11 & 0.01 & 99.99 & $\mathrm{sp}^{1.00}$ \\
\hline
\end{tabular}




\begin{tabular}{|c|c|c|c|c|c|c|}
\hline \multirow[t]{2}{*}{$\mathrm{C} 17 \mathrm{C} 18$} & 0.98523 & $\mathrm{C} 17$ & 47.89 & 33.83 & 66.17 & $\mathrm{sp}^{1.96}$ \\
\hline & & $\mathrm{C} 18$ & 52.11 & 35.31 & 64.69 & $\mathrm{sp}^{1.83}$ \\
\hline \multirow[t]{2}{*}{ C18C19 } & 0.98741 & $\mathrm{C} 18$ & 50.53 & 31.26 & 68.74 & $\mathrm{sp}^{2.20}$ \\
\hline & & C19 & 49.47 & 38.90 & 61.10 & $\mathrm{sp}^{1.57}$ \\
\hline \multirow[t]{2}{*}{ C18C23 } & 0.98648 & $\mathrm{C} 18$ & 50.60 & 33.41 & 66.59 & $\mathrm{sp}^{1.99}$ \\
\hline & & $\mathrm{C} 23$ & 49.40 & 35.22 & 64.78 & $\mathrm{sp}^{1.84}$ \\
\hline \multirow[t]{2}{*}{ C19N20 } & 0.99144 & C19 & 36.79 & 29.93 & 70.07 & $\mathrm{sp}^{2.34}$ \\
\hline & & N20 & 63.21 & 38.50 & 61.50 & $\mathrm{sp}^{1.60}$ \\
\hline \multirow[t]{2}{*}{$\mathrm{C} 21 \mathrm{~N} 20$} & 0.99036 & N20 & 62.29 & 37.66 & 62.34 & $\mathrm{sp}^{1.66}$ \\
\hline & & $\mathrm{C} 21$ & 37.71 & 28.33 & 71.67 & $\mathrm{sp}^{2.53}$ \\
\hline \multirow[t]{2}{*}{$\mathrm{N} 20-\mathrm{C} 21$} & 0.88387 & $\mathrm{~N} 20$ & 64.82 & 0.00 & 100.00 & $\mathrm{sp}^{1.00}$ \\
\hline & & $\mathrm{C} 21$ & 35.18 & 0.00 & 100.00 & $\mathrm{sp}^{1.00}$ \\
\hline \multirow[t]{2}{*}{ C21C24 } & 0.98323 & $\mathrm{C} 21$ & 49.72 & 33.60 & 66.40 & $\mathrm{sp}^{1.98}$ \\
\hline & & $\mathrm{C} 24$ & 50.28 & 33.39 & 66.61 & $\mathrm{sp}^{1.99}$ \\
\hline \multirow[t]{2}{*}{ C24N25 } & 0.99070 & $\mathrm{C} 24$ & 38.05 & 28.40 & 71.60 & $\mathrm{sp}^{2.52}$ \\
\hline & & N25 & 61.95 & 37.59 & 62.41 & $\mathrm{sp}^{1.66}$ \\
\hline \multirow[t]{2}{*}{$\mathrm{C} 26 \mathrm{~N} 25$} & 0.99168 & $\mathrm{~N} 25$ & 63.12 & 37.47 & 62.53 & $\mathrm{sp}^{1.67}$ \\
\hline & & $\mathrm{C} 26$ & 36.88 & 29.57 & 70.43 & $\mathrm{sp}^{2.38}$ \\
\hline \multirow[t]{2}{*}{$\mathrm{C} 26 \mathrm{C} 27$} & 0.99052 & $\mathrm{C} 26$ & 49.90 & 38.82 & 61.18 & $\mathrm{sp}^{1.58}$ \\
\hline & & $\mathrm{C} 27$ & 50.10 & 34.04 & 65.96 & $\mathrm{sp}^{1.94}$ \\
\hline \multirow[t]{2}{*}{$\mathrm{C} 1 \mathrm{H} 30$} & 0.98858 & $\mathrm{C} 1$ & 60.97 & 28.94 & 71.06 & $\mathrm{sp}^{2.46}$ \\
\hline & & $\mathrm{H} 30$ & 39.03 & 100.00 & & \\
\hline \multirow[t]{2}{*}{ C14H33 } & 0.98924 & $\mathrm{C} 14$ & 61.33 & 24.32 & 75.68 & $\mathrm{sp}^{3.11}$ \\
\hline & & H33 & 38.67 & 100.00 & & 1 \\
\hline
\end{tabular}

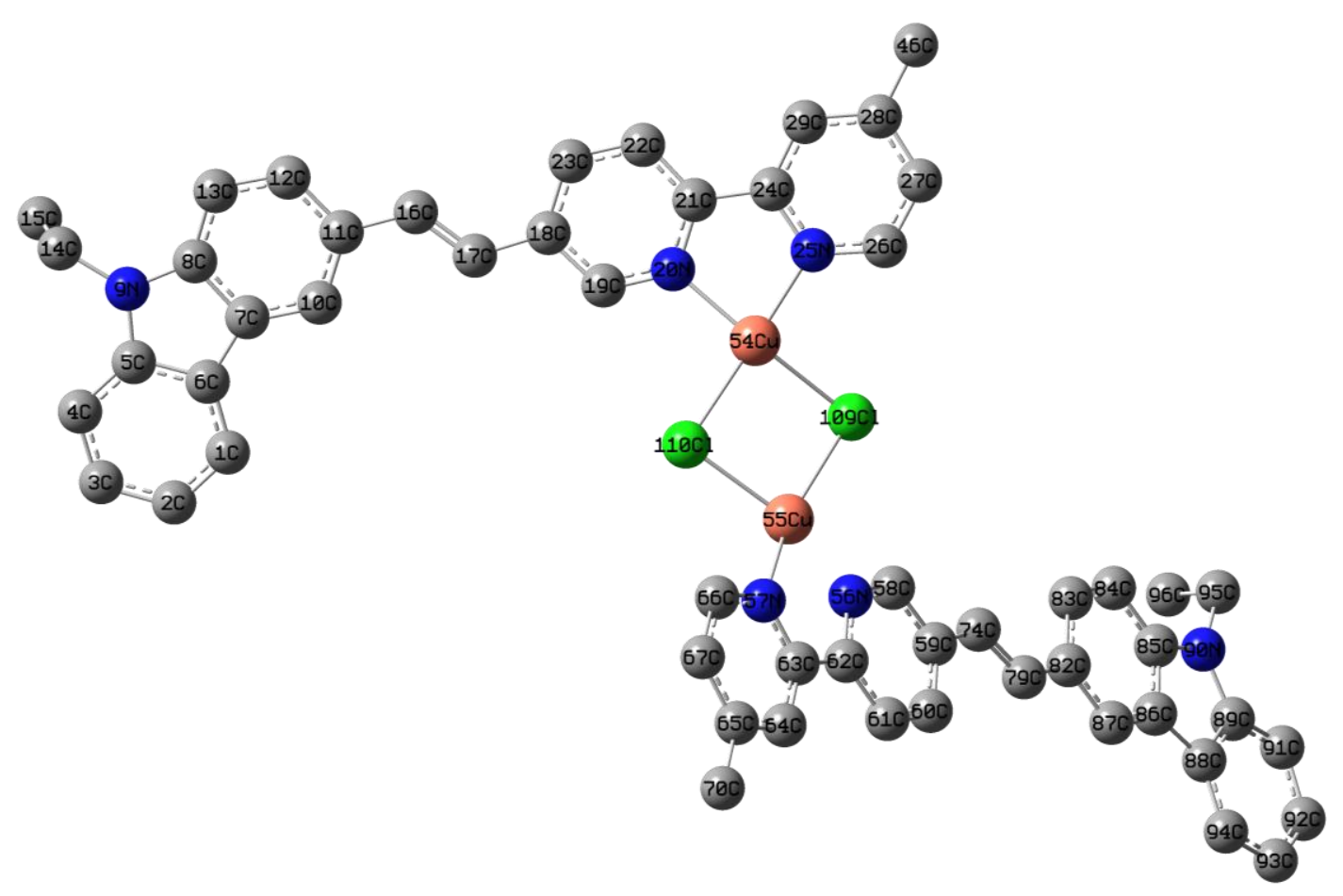

Fig. 1 Optimized structure of title compound with B3LYP/LanL2DZ level 


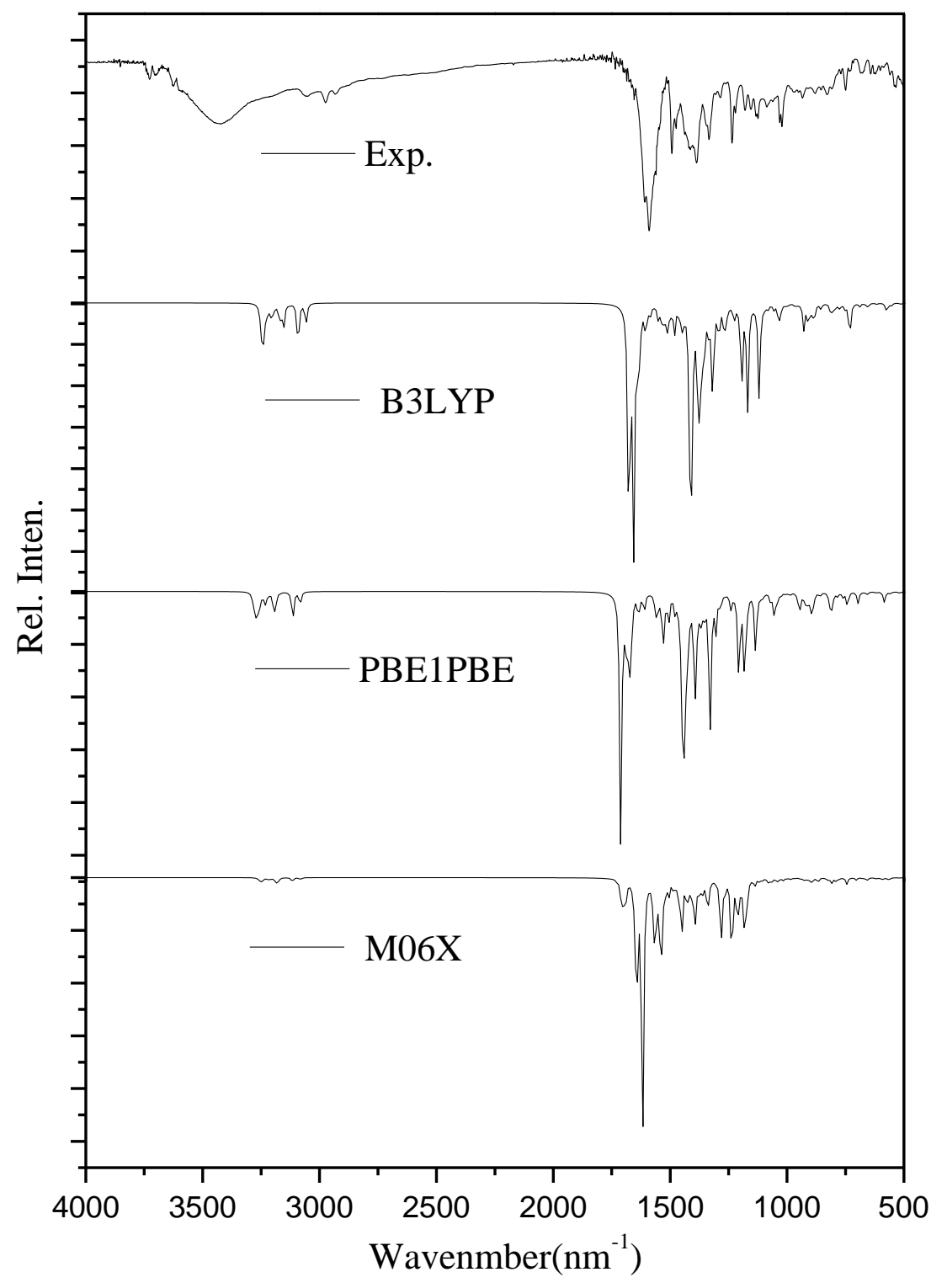

Fig 2 Experimental and calculated IR. a) Experimental IR; b) Calculated IR spectra with B3LYP method; c) Calculated IR spectra with PBE1PBE method 

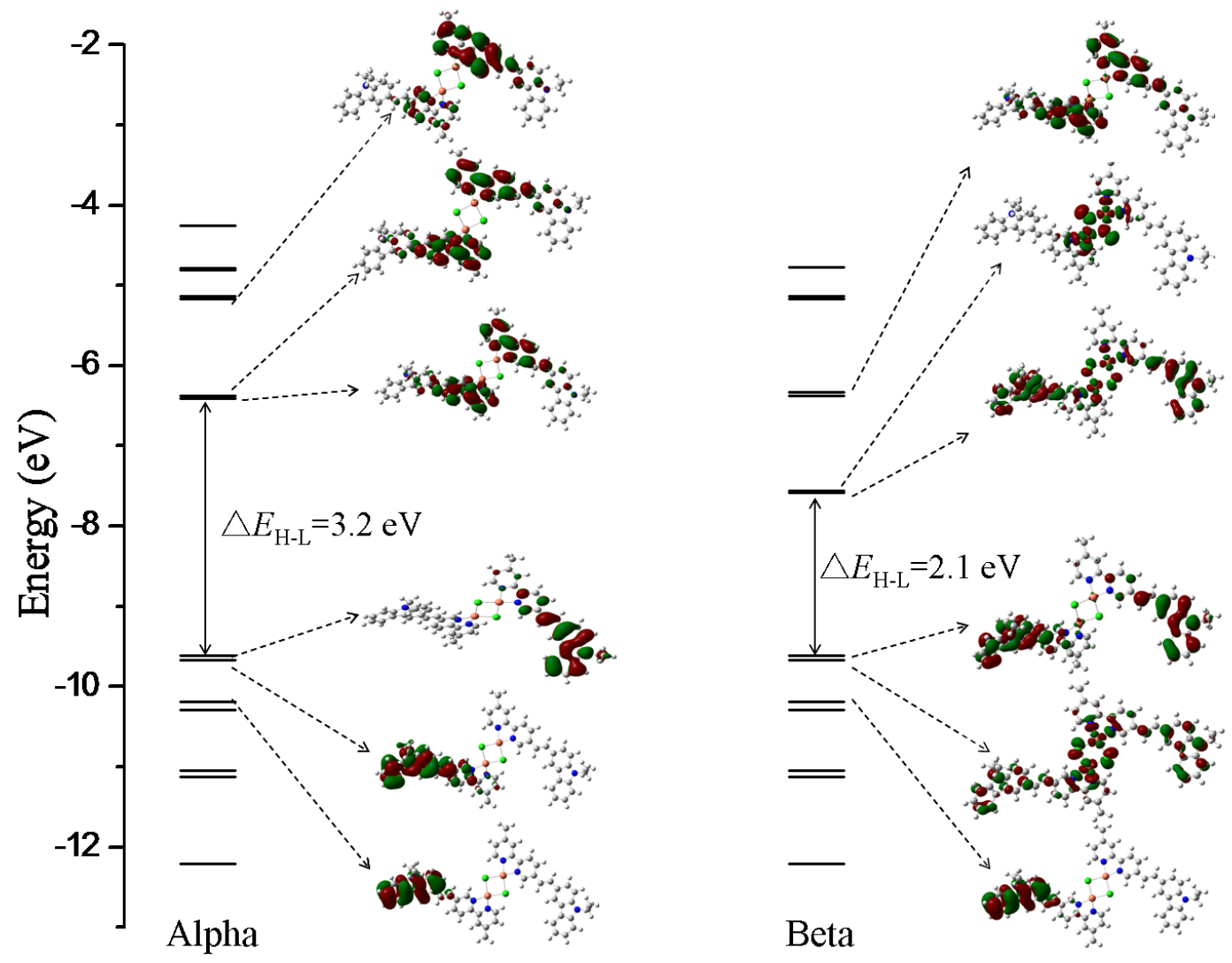

Fig.3 Energy levels and the 3D plots of the NHOMO and NLUMO of the compound 


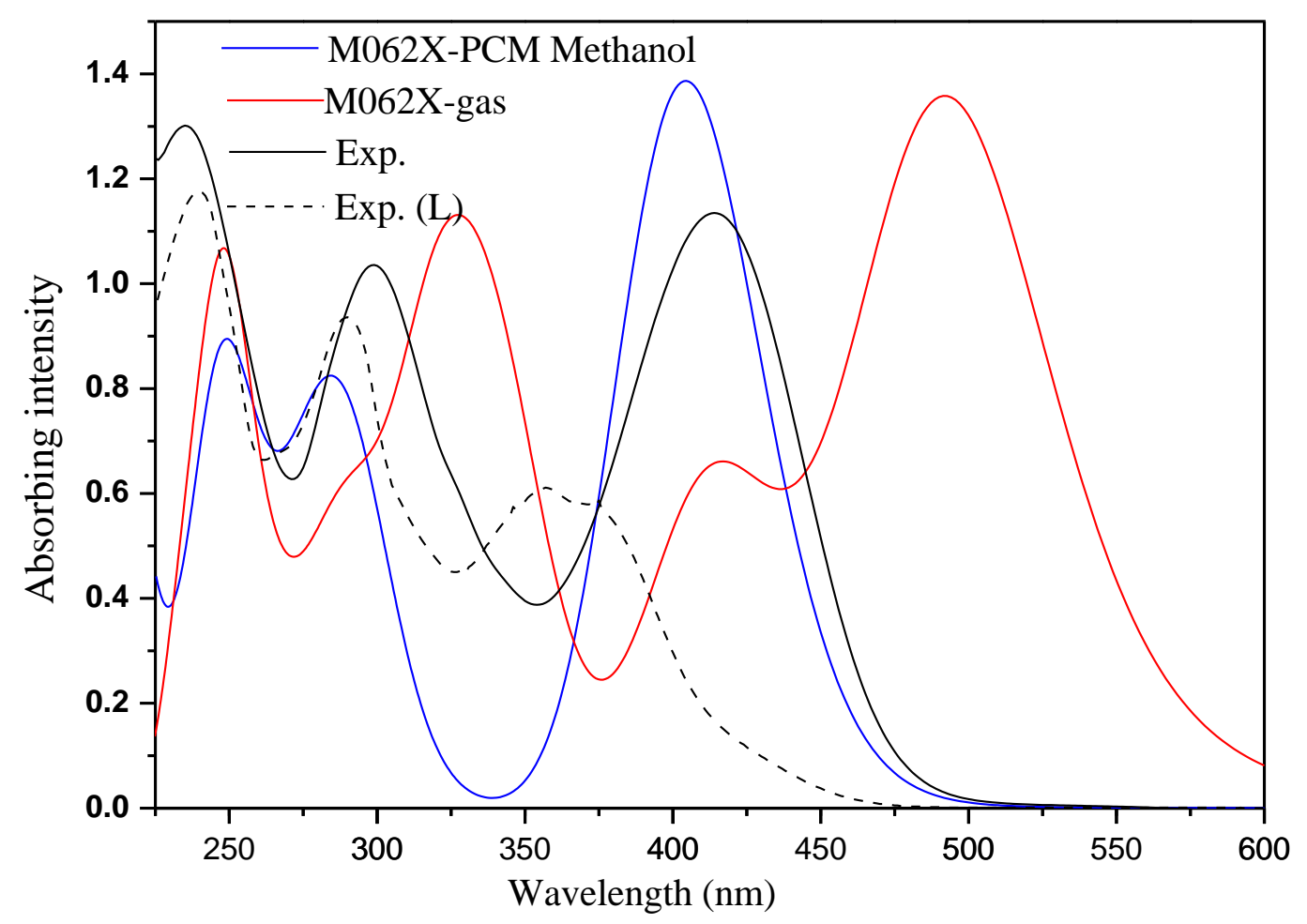

Fig. 4 Calculated UV-Vis with B3LYP and PBE1PBE methods. 

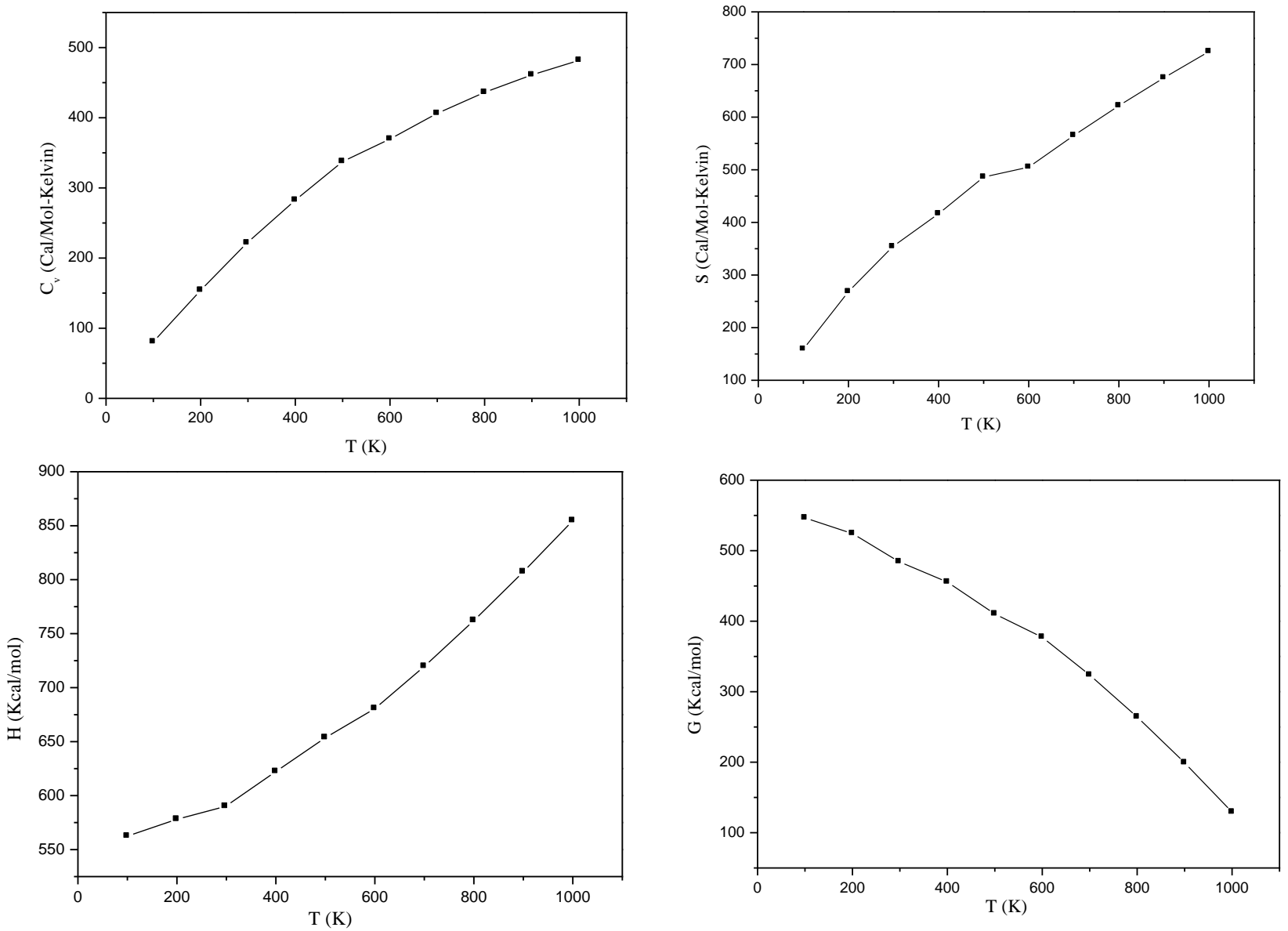

Fig. 5 The correlation of heat capacity $\mathrm{Cv}(\mathrm{a})$, entropy $\mathrm{S}(\mathrm{b})$, enthalpy $\mathrm{H}(\mathrm{c})$ and Gibbs free energy $\mathrm{G}(\mathrm{d})$ with temperature T). 


\section{Graphical abstract}

Experimental and DFT study of the structural and spectroscopic properties of $\left[\mathrm{Cu}_{2}(\mathrm{emppc})_{2} \mathrm{Cl}_{2}\right] \mathrm{Cl}_{2}$ has been reported

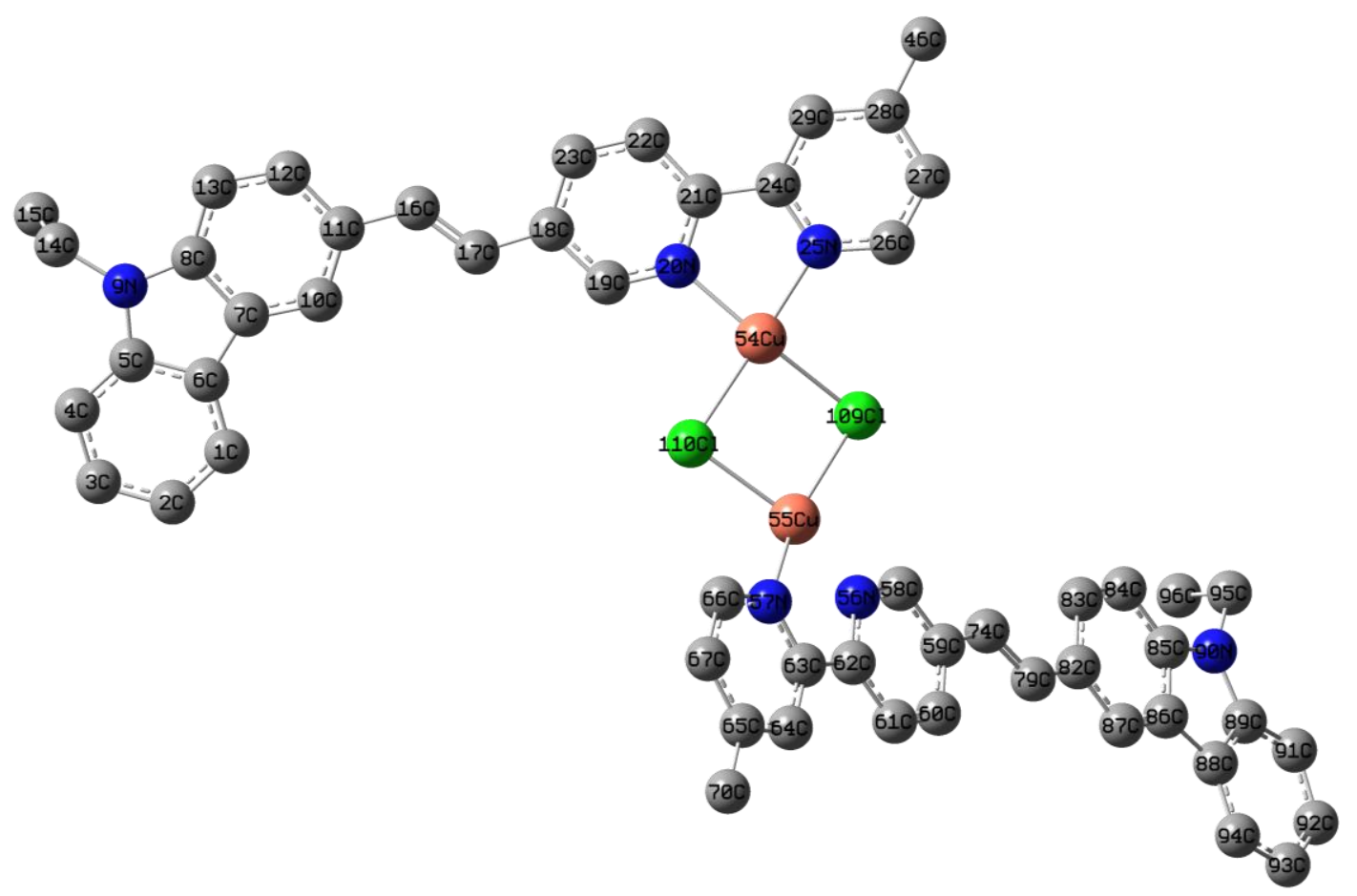

